FELIPE ENNE MENDES RIBEIRO

APLICAÇÃO DE UM MÉTODO DE SIMULAÇÃO EM UM

TERMINAL PORTUÁRIO DE GRANÉIS AGRÍCOLAS

São Paulo

2020 
FELIPE ENNE MENDES RIBEIRO

\title{
APLICAÇÃO DE UM MÉTODO DE SIMULAÇÃO EM UM TERMINAL PORTUÁRIO DE GRANÉIS AGRÍCOLAS
}

\author{
Dissertação apresentada à Escola Politécnica \\ da Universidade de São Paulo, para obtenção \\ do título de Mestre em Engenharia de Sistemas \\ Logísticos.
}

Área de Concentração:

Engenharia de Sistemas Logísticos

Orientador: Prof. Dr.

Rui Carlos Botter

São Paulo 
Autorizo a reprodução e divulgação total ou parcial deste trabalho, por qualquer meio convencional ou eletrônico, para fins de estudo e pesquisa, desde que citada a fonte.

Este exemplar foi revisado e corrigido em relação à versão original, sob responsabilidade única do autor e com a anuência de seu orientador.

São Paulo, de de

Assinatura do autor:

Assinatura do orientador:

Ribeiro, Felipe Enne Mendes

APLICAÇÃO DE UM MÉTODO DE SIMULAÇÃO EM UM TERMINAL

PORTUÁRIO DE GRANÉIS AGRÍCOLAS / F. E. M. Ribeiro -- versão corr. -- São

Paulo, 2020.

$79 \mathrm{p}$.

Dissertação (Mestrado) - Escola Politécnica da Universidade de São Paulo. Departamento de Engenharia de Transportes.

1.Simulação 2.Porto I.Universidade de São Paulo. Escola Politécnica. Departamento de Engenharia de Transportes II.t. 
FELIPE ENNE MENDES RIBEIRO

\title{
APLICAÇÃO DE UM MÉTODO DE SIMULAÇÃO EM UM TERMINAL PORTUÁRIO DE GRANÉIS AGRÍCOLAS
}

\author{
Dissertação apresentada à Escola Politécnica \\ da Universidade de São Paulo, para obtenção \\ do título de Mestre em Engenharia de Sistemas \\ Logísticos.
}

Área de Concentração:

Engenharia de Sistemas Logísticos

Orientador: Prof. Dr.

Rui Carlos Botter

São Paulo 


\section{FOLHA DE APROVAÇÃO}

Felipe Enne Mendes Ribeiro

Aplicação de um método de simulação em um terminal portuário de granéis agrícolas

Dissertação apresentada à Escola Politécnica da Universidade de São Paulo para obtenção do título de Mestre em Engenharia de Sistemas Logísticos.

Área de Concentração: Sistemas Logísticos

Aprovado em:

Banca Examinadora

Prof. Dr.

Instituição: Assinatura

Prof. Dr.

Instituição: Assinatura

Prof. Dr.

Instituição: Assinatura 


\section{DEDICATÓRIA}

A Deus, ser supremo acima de todas as coisas, o qual me deu saúde e força para superar os obstáculos.

A todos os meus professores da universidade, que foram essenciais na minha trajetória acadêmica.

A minha família, mas principalmente aos meus pais Josias e Debora. Agradeço pela compreensão, pela presença e pelo incansável apoio ao longo do período de elaboração deste trabalho. 


\section{AGRADECIMENTOS}

Aos amigos feitos durante a elaboração da dissertação pela colaboração.

Ao Prof. Dr. Rui Carlos Botter, pela atenção e apoio durante todo o processo de elaboração desta dissertação.

À Escola Politécnica da Universidade de São Paulo, pela oportunidade de realização do curso de mestrado. 


\section{RESUMO}

Os portos são importantes para o crescimento econômico do país, pois o comércio internacional está relacionado com as movimentações portuárias. Portanto melhorar a capacidade dos portos atenuando as perdas e aumentando a sua eficiência de recebimento/envio de mercadorias são relevantes diante do mundo globalizado.

O terminal portuário é uma infraestrutura do porto que tem como atribuição a exploração das instalações portuárias, sendo essencial para as operações logísticas de exportação. No entanto o terminal portuário é um sistema dinâmico e complexo em que as operações portuárias e os processos produtivos são aleatórios. Problemas logísticos podem ser identificados, acarretando custos como por exemplo o de vendas perdidas pelo não-atendimento ao planejamento. Portanto a construção de um modelo para simulação da operação desse sistema pode ser de grande utilidade. A busca das possíveis soluções para maior eficiência é possibilitada pela realização de experiências, de observação, de aprendizagem e de avaliação do comportamento do sistema mediante a mudança do estado das variáveis de decisão.

O objetivo principal deste trabalho foi construir um modelo de simulação dos recebimentos de grãos de um terminal portuário e estudar o comportamento desse sistema perante mudança de estado das variáveis existentes. O comportamento do sistema foi avaliado por meio da análise da medida de rendimento global, definido pela taxa de ocupação dos recursos e escoamento global no horizonte de um ano. 0 modelo utiliza a técnica de simulação discreta em que foi construída uma lógica para discretizar os processos. O estudo possibilitou avaliar a capacidade de oferta de escoamento de grão do terminal portuário durante o período de um ano. A forma de operação no qual o sistema oferece a maior oferta foi analisada entre os cenários estudados.

Palavras-Chave: Simulação, terminal portuário e granéis agrícolas. 


\begin{abstract}
Ports are important for the country's economic growth, as international trade is related to port movements. Therefore, improving port capacity by mitigating losses and increasing their efficiency of receiving/shipping goods is relevant in the globalized world.

The port terminal is a port infrastructure that is responsible for operating port facilities and is essential for export logistics operations. However, the port terminal is a dynamic and complex system in which port operations and production processes are random. Logistical problems can be identified, leading to costs such as lost sales due to non-compliance with planning. Therefore, the construction of a model to simulate the operation of this system can be very useful. The search for possible solutions for greater efficiency is made possible by conducting experiments, observing, learning, and evaluating the behavior of the system through decision variables.

The main objective of this work was to construct a simulation model of grain receipts from a port terminal and to study the behavior of this system in the face of changing the state of existing variables. The behavior of the system was assessed by analyzing the overall yield measure, defined by the rate of resource occupation and global runoff over the one-year horizon. The model uses the discrete simulation technique in which logic was built to discretize the processes. The study made it possible to assess the supply capacity of grain flow from the port terminal over the period of one year. The form of operation in which the system offers the largest offer was analyzed among the scenarios studied.
\end{abstract}

Keywords: Simulation, port terminal and agricultural bulk. 


\section{LISTA DE FIGURAS}

Figura 1 - Exportação das principais mercadorias de granéis sólidos 2

Figura 2 - Evolução da movimentação portuária de granéis sólidos em toneladas 3

$\begin{array}{ll}\text { Figura } 3 \text { - Tipos de estudo do sistema } & 19\end{array}$

Figura 4 - Estudo de simulação $\quad 27$

Figura 5 - Principais rodovias para o Porto de Santos 41

Figura 6 - Ecopátio do Porto de Santos em Cubatão 43

Figura 7 - Desenho esquemático: tombador empregado para descarga de caminhões

45

Figura 8 - Modelo Conceitual de Descarga dos Caminhões 48

Figura 9 - Modelo Conceitual de Descarga dos Trens 49

Figura 10 - Representação do sistema de filas de descarregamento (da entrada até as

filas) $\quad 55$

Figura 11 - Representação do sistema de filas de descarregamento (das filas até a saída do terminal) 


\section{LISTA DE GRÁFICOS}

Gráfico 1 -Variável em um sistema discreto 


\section{LISTA DE TABELAS}

Tabela 1 - Quantidade de carga transportada no cenário 1

Tabela 2 - Número de descargas por moegas realizadas no cenário 1

Tabela 3 - Tempo médios das filas dos caminhões no cenário 1

Tabela 4 - Porcentagem de trabalho, espera e bloqueio no cenário $1 \quad 60$

Tabela 5 - Quantidade de carga transportada no cenário $2 \quad 61$

Tabela 6 - Número de descargas realizadas no cenário $2 \quad 62$

Tabela 7 - Tempo médios das filas dos caminhões no cenário 2

Tabela 8 - Porcentagem de trabalho, espera e bloqueio no cenário $2 \quad 63$

Tabela 9 - Quantidade de carga transportada no cenário $3 \quad 64$

Tabela 10 - Número de descargas realizadas no cenário $3 \quad 64$

Tabela 11 - Tempo médios das filas dos caminhões no cenário $3 \quad 65$

Tabela 12 - Porcentagem de trabalho, espera e bloqueio no cenário $3 \quad 66$

Tabela 13 - Quantidade de carga transportada no cenário $4 \quad 67$

Tabela 14 - Número de descargas realizadas no cenário $4 \quad 67$

Tabela 15 - Tempo médios das filas dos caminhões no cenário 4

Tabela 16 - Porcentagem de trabalho, espera e bloqueio no cenário 4

Tabela 17 - Seis melhores situações $\quad 70$

Tabela 18 - Resultados da validação 


\section{LISTA DE QUADROS}

Quadro 1 - Critérios para identificar variáveis e gargalos logísticos 


\section{LISTA DE ABREVIATURAS E SIGLAS}

FGV - Fundação Getulio Vargas

CODESP - Companhia Docas do Estado de São Paulo

PO - Pesquisa Operacional

ANTAQ - Agência Nacional de Transportes Aquaviários

SCOOP - Scientific Computation of Optimal Programs

SOBRAPO - Sociedade Brasileira de Pesquisa Operacional 


\section{LISTA DE SÍMBOLOS}

$\mathrm{t}$ - Toneladas

$\mathrm{t} / \mathrm{h}$ - Toneladas por hora 


\section{SUMÁRIO}

1. INTRODUÇÃO 1

1.1. Relevância do tema 1

1.2. Definição do problema 5

1.3. Objetivos 6

1.4. Delineamento do Trabalho 7

2. REVISÃO BIBLIOGRÁFICA 10

2.1. Pesquisa operacional 10

2.2. Natureza da pesquisa operacional 11

2.3. Vantagem do uso da pesquisa operacional 12

2.4. Técnicas de pesquisa operacional 13

2.5. Simulação na Pesquisa Operacional 14

2.6. Conceitos Fundamentais Sobre O Método De Simulação 15

3. A SIMULAÇÃO DE SISTEMAS 21

3.1. Natureza da simulação 21

3.2. Quando a simulação não é uma ferramenta adequada 22

3.3. Quando a simulação é uma ferramenta adequada 23

3.4. Método de condução para o projeto de simulação 24

3.5. Simulação de sistemas em terminais portuários 30

3.6. Conclusão da revisão bibliográfica 38

4. SISTEMA DE RECEBIMENTO DO TERMINAL PORTUÁRIO 40

4.1. Transporte de cargas agrícolas no Porto de Santos 41

4.2. Dados Específicos 44

4.3. Caracterização Do Estudo De Caso 45

5. MODELO PROPOSTO 50

5.1. Dados necessários para a pesquisa 50

5.2. Descrição do modelo de simulação 51

5.3. Diagrama no terminal portuário 54

5.4. Ordens de despacho dos caminhões 56

5.5. Diferenças entre os cenários 56

6. ANÁLISE DE CENÁRIOS 58

6.1. Análise do cenário $1 \quad 58$

6.2. Análise do cenário $2 \quad 61$

6.3. Análise do cenário $3 \quad 63$

6.4. Análise do cenário $4 \quad 66$ 
6.5. Análise dos cenários

6.6. Validação do modelo

7. CONCLUSÕES E RECOMENDAÇÕES 72

REFERÊNCIAS BIBLIOGRÁFICAS 


\section{INTRODUÇÃO}

Os portos são importantes para o desenvolvimento de um país e seu crescimento econômico. Com o aumento da eficiência, redução dos custos e melhora no nível de serviço dos portos, a economia do país é beneficiada (Tovar e Ferreira, 2006).

As mercadorias que os portos movimentam podem ser divididas em: granel sólido, granel líquido e carga geral. Comparando-se os modais de transporte, constata-se que o rodoviário é o mais caro, sendo o ferroviário 3,5 vezes mais barato e o hidroviário 6,22 vezes mais barato do que o primeiro (Colavite e Konishi, 2015).

O desenvolvimento do comércio internacional está relacionado com as movimentações portuárias, sendo que a maioria das mercadorias comercializadas no mundo são transportadas por navios. Logo, participar do comércio internacional é um fator que gera enriquecimento para o país (Oliveira, 2000).

Nesse sentido, facilitar o escoamento de mercadorias e reduzir as perdas nos transportes tornam-se fatores importantes para a economia. Assim, os trabalhos que visam melhorar a eficiência dos portos tornam-se relevantes neste mundo globalizado.

Desta forma, a construção de um modelo utilizando a técnica de simulação computacional é pertinente, pois torna possível a realização de experiências, a observação, a aprendizagem e a avaliação do comportamento do sistema analisado mediante a mudança dos estados das variáveis de decisão, assim permitindo encontrar soluções efetivas na busca da minimização dos custos resultantes da operação do sistema.

\subsection{Relevância do tema}

\subsubsection{O que é um terminal portuário}

Um porto é uma área protegida onde os navios podem ser carregados, descarregados, reabastecidos ou reparados com segurança (Tsinker, 1997). Ele é composto de vários terminais, equipamentos portuários, fundeadouro, canal de acesso ao porto, vias de acesso ferroviárias, rodoviárias e fluviais (Keedi e Mendonça, 2000).

Um terminal portuário é uma infraestrutura situada num porto destinado a embarque, descarga e armazenamento de mercadorias (Santos Port Authority, 2020). 
Os terminais são normalmente especializados em tipos de cargas ou de navios (Keedi e Paulo, 2000).

Esses locais consistem em uma infraestrutura onde se empregam profissionais de diversas áreas, gerando um movimento econômico não só na região portuária como também nas adjacências.

\subsubsection{Importância da atividade portuária}

No Brasil, em 2019, a movimentação total portuária foi de 1.104 milhões de toneladas, sendo $61,6 \%$ de granéis sólidos, movimentando um total 680 milhões de toneladas. Em 2019, as exportações de soja, milho e açúcar foram respectivamente de 92,3 milhões de toneladas, 55,7 milhões de toneladas e 16,4 milhões de toneladas (ANTAQ ${ }^{1}$, 2020). O figura 1 apresenta o volume de exportação das principais mercadorias de granéis sólidos em porcentagem, e o figura 2 expõe a evolução da movimentação portuária de granéis sólidos de 2010 a 2019 (ANTAQ, 2020).

Figura 1 - Exportação das principais mercadorias de granéis sólidos

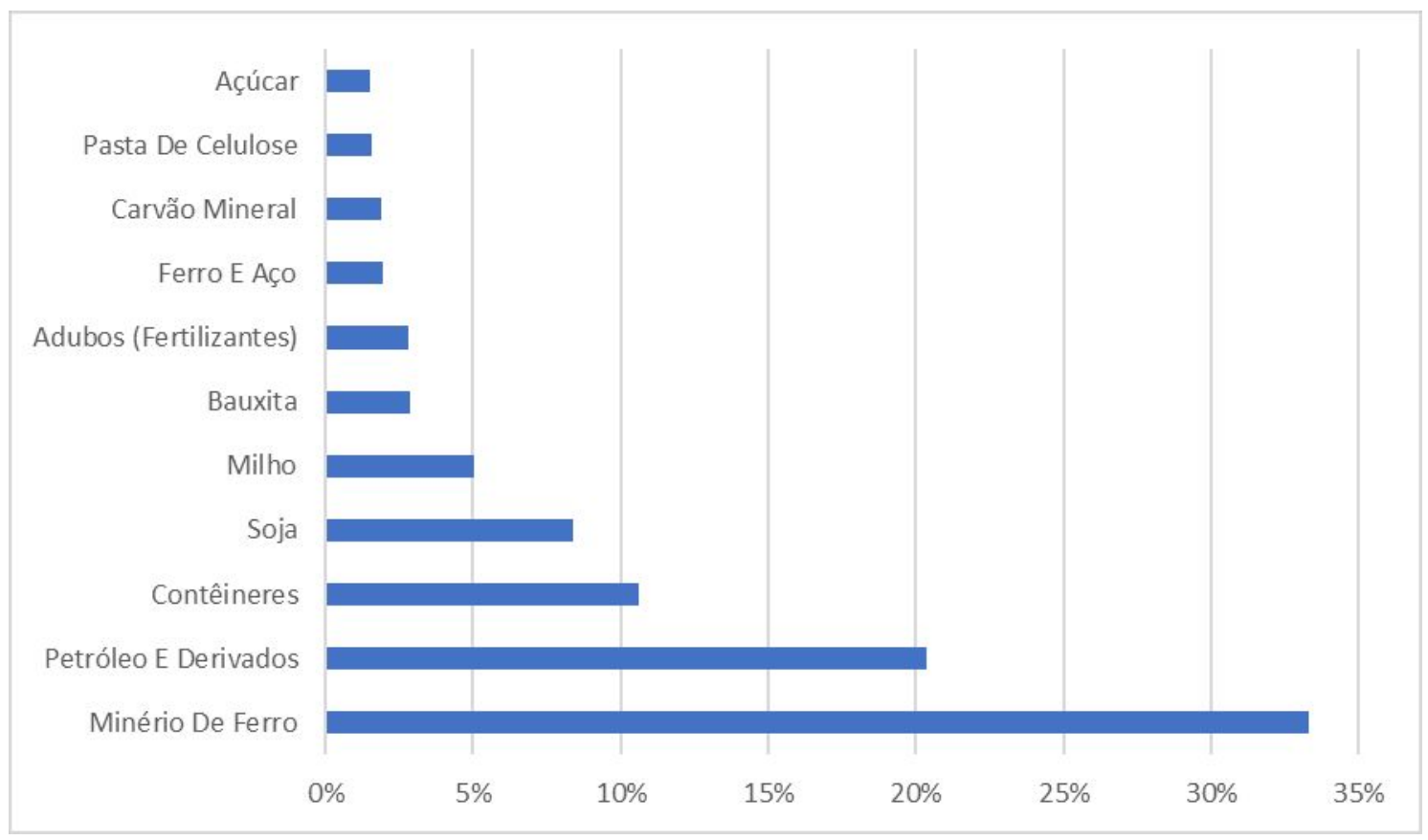

Fonte: ANTAQ (2020).

\footnotetext{
${ }^{1}$ ANTAQ - Agência Nacional de Transportes Aquaviários.
} 
Figura 2 - Evolução da movimentação portuária de granéis sólidos em toneladas

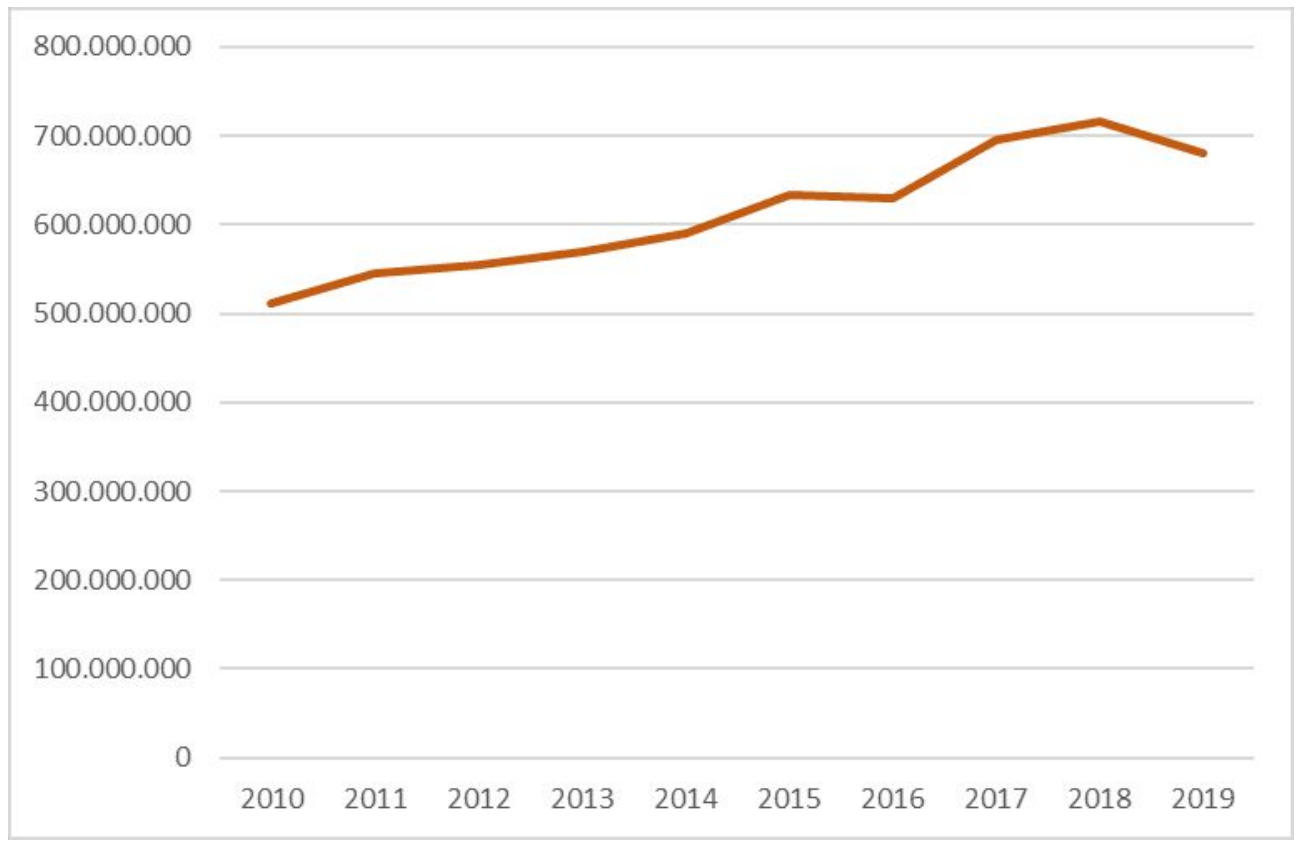

Fonte: ANTAQ (2020).

Os portos podem ser divididos em portos públicos e portos privados. Os portos privados respondem por $66,4 \%$ da movimentação portuária e os portos públicos ficam com 33,6\%. Dos portos privados o maior é o terminal marítimo de Ponta da Madeira, com $17,2 \%$ da movimentação portuária, e dos portos públicos o de Santos é o maior, com 9,6\% da movimentação (ANTAQ, 2020). Este estudo foi realizado com base nos dados do Porto de Santos.

O complexo portuário de Santos é o maior da América Latina, e nele movimenta-se quase um terço das trocas comerciais brasileiras. Este complexo abrange os estados de São Paulo, Minas Gerais, Mato Grosso, Mato Grosso do Sul e Goiás, estados que concentram mais de $60 \%$ do PIB brasileiro. Ele se conecta à sua área de influência por meio de ampla rede de rodovias, ferrovias e hidrovias que integram a principal cadeia logística do país (CODESP, 2015).

\subsubsection{Motivo do foco na carga a granel}

$\mathrm{Na}$ infraestrutura terrestre portuária há trocas de produtos entre os navios, por meio de ferrovias, rodovias, dutos e correias transportadoras dentro dos limites da área do porto. A infraestrutura aquaviária é composta dos canais de acesso aos 
portos, bacias de evolução, quebra-mares e berços de atracação. Para garantir o transporte seguro nessas áreas, são utilizados equipamentos para movimentação e armazenagem de mercadorias, tais como guindastes, esteiras e armazéns (Lacerda, 2005).

É no terminal de recebimento de carga a granel, que será o foco do estudo, onde ocorre o gargalo. Goldratt e Cox (2006) definem gargalo como um recurso dentro de um sistema de produção cuja capacidade é menor que a demanda alocada para esse recurso.

Em outras palavras, um gargalo é um recurso incapaz de atender a demanda que the é requisitada. O gargalo, na logística, é uma restrição que cria um obstáculo ao atendimento da demanda de bens e serviços, gerando filas que atrapalham o fluxo da cadeia logística. E geralmente esse obstáculo impede que a produção ocorra de maneira otimizada, segundo a Fundação Getúlio Vargas (2006).

Normalmente, o transporte de mercadorias apresenta um dos maiores gargalos e possui o maior custo logístico na maior parte das empresas, chegando a compreender até dois terços dos gastos logísticos (Ballou, 2006).

Gaban e Guarnieri (2015) realizaram em seu artigo uma revisão sistemática da literatura identificando os principais gargalos ligados ao setor da logística agroindustrial. A Quadro 1 mostra os resultados dessa pesquisa. 
Quadro 1 - Critérios para identificar variáveis e gargalos logísticos

\begin{tabular}{|c|c|}
\hline GARGALOS & AUTORES \\
\hline $\begin{array}{l}\text { Baixo Grau de Competitividade } \\
\text { Intermodal }\end{array}$ & Correa e Ramos (2010); Gaban (2013); Ripoll (2010) e Rodrigues (2007). \\
\hline $\begin{array}{l}\text { Uso Excessivo e Indevido de uma } \\
\text { Única Modalidade de Transporte }\end{array}$ & CNT (2014); Naves (2012); Bowersox e Closs (2001); Ripoll (2010). \\
\hline Déficit em Armazenagem & $\begin{array}{l}\text { Oliveira et al. (2012); Biagi, Bertol e Carneiro (2002); Sasseron (1995); } \\
\text { Ferrari (2006); Rodrigues (2007); Conab (2015); Naves (2012); Ripoll } \\
\text { (2010). }\end{array}$ \\
\hline Excesso de Burocracia & $\begin{array}{l}\text { Erhart e Palmeira (2006); ESALQ-LOG (2014); Mitsutani (2010); } \\
\text { Capdeville (2010). }\end{array}$ \\
\hline Problemas Diversos em Portos & $\begin{array}{l}\text { Oliveira et al. (2012); Naves (2012); Campos Neto et al. (2009); Ripoll } \\
\text { (2010); Sá e Mendonça (2010/2011). }\end{array}$ \\
\hline Infraestrutura Deficiente & $\begin{array}{l}\text { Conab (2015); Oliveira et al. (2012); Biagi, Bertol e Carneiro (2002); } \\
\text { ESALQ-LOG (2014); Erhart e Palmeira (2006); Correa e Ramos (2010); } \\
\text { Gaban (2013); Ojima e Yamakami (2006); CEL/CPPEAD-UFRJ (2008); } \\
\text { ANTF (2015); Caixeta Filho e Gameiro (2001); Campos Neto et al. (2009); } \\
\text { Mitsutani (2010); Dubke (2006); Souza et al. (2012); Rodrigues (2007); } \\
\text { Capdeville (2010); Naves (2012); Ripoll (2010); Sá e Mendonça } \\
\text { (2010/2011). }\end{array}$ \\
\hline $\begin{array}{l}\text { Custo Total Elevado, Excesso de } \\
\text { Gastos, Custos Operacionais } \\
\text { Altos }\end{array}$ & $\begin{array}{l}\text { Biagi, Bertol e Carneiro (2002); ESALQ-LOG (2014); Correa e Ramos } \\
\text { (2010); Gaban (2013); CEL/CPPEAD-UFRJ, 2008; Caixeta Filho e } \\
\text { Gameiro (2001); Dubke (2006); Neves e Conejero (2007); Rodrigues } \\
\text { (2007); Capdeville (2010); Ripoll (2010); Gameiro (2003). }\end{array}$ \\
\hline Perdas Desnecessárias & Ferrari (2006); Erhart e Palmeira (2006). \\
\hline $\begin{array}{l}\text { Sistema Ferroviário Precário e } \\
\text { baixo/não uso }\end{array}$ & $\begin{array}{l}\text { Ojima e Yamakami (2006); CEL/CPPEAD-UFRJ, 2008; ANTF (2015); } \\
\text { Caixeta Filho e Gameiro (2001); Campos Neto et al. (2009); Souza et al. } \\
\text { (2012); Sá e Mendonça (2010/2011); Ripoll (2010). }\end{array}$ \\
\hline Greves & Ripoll (2010). \\
\hline
\end{tabular}

Fonte: (Gaban e Guarnieri, 2015).

Analisando-se o terminal portuário, em conjunto com os tomadores de decisão, acredita-se que o gargalo se encontra principalmente na recepção dos produtos, tendo maior relevância o encontro entre as interfaces rodoviária e ferroviária.

\subsection{Definição do problema}

Pode-se definir o problema desta pesquisa com a seguinte pergunta: Analisando as operações de recebimento de caminhões e vagões do terminal portuário de granéis agrícolas do porto de Santos, como aumentar a sua capacidade de exportação? 
A partir desta pergunta geral, levantam-se dois questionamentos complementares, quais sejam:

- Como esses veículos devem ser alocados a cada posição de descarregamento durante um determinado período, de modo a aumentar a capacidade de recepção do sistema? Conhecendo as restrições de recursos e características definidas (comprimento e capacidade) para desembarque de caminhões e de trens;

- Como a programação de atendimento de caminhões e vagões que chegam ao terminal deve ser integrado de forma a maximizar a capacidade de recepção?

\subsection{Objetivos}

\subsubsection{Objetivo geral}

Esta pesquisa tem como objetivo estudar as formas de despacho dos caminhões e a organização das filas no terminal portuário, visando aumentar a capacidade de escoamento no terminal, considerando desde os agendamentos dos caminhões e as chegadas dos trens ao terminal portuário até o escoamento dos grãos.

\subsubsection{Objetivos específicos}

- Investigar técnicas de simulação aplicadas em terminais portuários, com a finalidade de entender como é utilizada a simulação;

- Caracterizar o recebimento de grãos do terminal portuário;

- Construir um modelo de simulação do recebimento de grãos do terminal portuário; 
- Avaliar as operações de recebimento de grão do terminal portuário de Santos através da simulação.

\subsection{Delineamento do Trabalho}

\subsubsection{Importância do Tema}

Ao otimizar o recebimento de caminhões e vagões contribui-se para a redução de custos operacionais e aumentar o fluxo de exportações do terminal, consequentemente, gerando riquezas.

O tema proposto para a pesquisa, Aplicação de um Método de Simulação em um Terminal Portuário de Granéis Agrícolas, está abordado no subitem 1.1 do capítulo 1 deste trabalho (Relevância do Tema). Nesse subitem foi discutida a importância dos portos na economia, e o objetivo do trabalho foi buscar a melhoria do recebimento de granéis agrícolas em um terminal portuário.

\subsubsection{Definição do Problema}

No subitem 1.2 - Definição do Problema, e no subitem 1.3 - Objetivos, foi definido o problema. No capítulo 4 - Sistema de Recebimento do Terminal Portuário, foi abordado o sistema de recebimento de grãos do terminal portuário e a caracterização do estudo de caso.

\subsubsection{Revisão bibliográfica}

A revisão bibliográfica foi apresentada nos capítulos 2 - Revisão Bibliográfica e 3 A Simulação de Sistemas. Ela consiste em consultas a artigos, periódicos, livros, páginas especializadas da internet e outros trabalhos de pós-graduação. Essa revisão permitiu a realização de uma investigação das aplicações de modelagem em terminais portuários, das técnicas (utilizadas pelos autores para modelagem), das características envolvidas, dos conceitos e dos métodos de condução de projetos de simulação. 


\subsubsection{Método de Pesquisa}

Segundo Gavira (2003), para o aprimoramento e análise das operações de uma empresa a Pesquisa Operacional (PO) é muito utilizada e valorizada. De acordo com Neto (2006), a otimização e incertezas são temas de estudos recorrentes nesse tipo de pesquisa, que faz uso de duas categorias principais de métodos matemáticos:

- Otimização: Programação linear, não linear, inteira, dinâmica;

- Probabilidade aplicada: Técnicas de teoria das filas, modelos de estoques, simulação de eventos discretos.

Quando a complexidade é grande, torna-se inviável a utilização isolada da otimização, pois as operações matemáticas ficam muito extensas e o cálculo se torna complexo. Logo, nesse cenário se procurou utilizar a simulação, porque ela consegue modelar as características complexas do sistema, reduzindo a dificuldade do modelo a ser estudado (Law e Kelton, 1991).

Como será visto no capítulo 4, Sistema de Recebimento do Terminal Portuário, a questão proposta envolve o sistema de recebimento de grãos em um terminal que utiliza o modal rodoviário e o ferroviário para recebimento.

Com base no que foi trabalhado neste item e na revisão bibliográfica (abordada nos capítulos 2 e 3), verificou-se que a técnica de simulação é o método matemático mais adequado para o tratamento desse problema.

\subsubsection{Modelagem Conceitual e Construção do Modelo Computacional}

No capítulo 4, Sistema de Recebimento do Terminal Portuário, foi apresentado o modelo conceitual de recebimento do Terminal Portuário e no capítulo 5 , Modelo Proposto, foi apresentado o modelo de simulação utilizado. 


\subsubsection{Planejamento da Investigação}

No capítulo 5, Modelo Proposto, foi mostrado o planejamento da investigação. Com a finalidade de simular os recebimentos de grãos em um terminal portuário e obter os resultados para atingir os objetivos descritos no item 1.3, foram realizados os seguintes experimentos com o modelo de simulação: descrição dos dados necessários para a pesquisa, validação do modelo com base nos dados que passam pelo terminal portuário e avaliação do comportamento do terminal nos diferentes cenários considerados.

\subsubsection{Análise dos Resultados, Elaboração das Conclusões e Recomendações}

Nesta etapa foram feitas a interpretação e a análise dos dados. A análise deve ser realizada para atender os objetivos da pesquisa, no sentido de comparar e confrontar dados e provas. Essa parte foi apresentada no capítulo 6 - Análise de Cenários, e no capítulo 7 - Conclusões e Recomendações. 


\section{REVISÃO BIBLIOGRÁFICA}

Este capítulo aborda a revisão bibliográfica de artigos, periódicos, livros e anais, visando estudar a pesquisa operacional com foco em simulação através de temas que norteiam o desenvolvimento desta dissertação.

\subsection{Pesquisa operacional}

A partir da Revolução Industrial, a complexidade das organizações cresceu em demasia, com as simples oficinas de artesãos se tornando grandes e complexas empresas. O aumento da divisão de trabalho e das responsabilidades gerenciais foi importante para essa evolução na forma de produção. Então surgiram novos problemas com o crescimento da especialização, apesar de os resultados da produção na Revolução Industrial terem sido bons. Um desses problemas é a tendência de unidades de uma organização a se isolarem e se tornarem autônomas, com seus próprios objetivos e sistemas de valor, perdendo a visão de como suas atividades se encaixam na empresa como um todo. As necessidades diferem entre as unidades: algo que pode ser melhor para uma pode prejudicar a outra, o que pode ocasionar conflitos na empresa. Nessa situação, como uma organização complexa irá alocar os recursos disponíveis da maneira mais eficiente? Para resolver esse tipo de problema (necessidade de encontrar a melhor solução) foram criadas as condições necessárias para o surgimento da pesquisa operacional (PO) (Hillier e Lieberman, 2006).

O termo em inglês operational research foi cunhado na Inglaterra durante a Segunda Guerra Mundial por um superintendente de estação chamado A. P. Rowe, que estava encarregado de examinar a eficiência das técnicas de operações de experimentos de interceptação de radar. Então, em 1941, foi criada a Seção de Pesquisa Operacional do Comando da Força Aérea de Combate, que envolvia a manutenção, inspeção e escolha dos aviões para o combate (Arenales et al., 2007).

Segundo Hillier e Lieberman (2006), dois fatores contribuíram para o crescimento da utilização da pesquisa operacional.

- Desenvolvimento considerável das técnicas da pesquisa operacional. Após a guerra, os cientistas que tinham participado das equipes de $\mathrm{PO}$ ou que ouviram falar a respeito ficaram motivados a aprimorar mais esse campo, o 
que resultou em avanços importantes. Muitas ferramentas da pesquisa operacional, como programação linear, programação dinâmica e teoria das filas foram desenvolvidas antes do final dos anos 1950.

- Abordagem do desenvolvimento da revolução computacional. Problemas complexos normalmente tratados pela pesquisa operacional necessitam (para uma abordagem eficiente) de um grande volume de processamento de cálculos. As resoluções desses cálculos à mão seriam uma hipótese inviável. Por essa razão, a criação de computadores com a capacidade de realizar cálculos matemáticos de forma muito mais rápida que um ser humano ajudou a pesquisa operacional a se desenvolver. A partir de 1980 houve o desenvolvimento de computadores pessoais cada vez melhores com pacotes de software que poderiam ser utilizados na pesquisa operacional, permitindo assim o uso deste método por um número maior de pessoas. Atualmente muitas pessoas conseguem ter pronto acesso a um software de pesquisa operacional. Consequentemente, muitos computadores são usados rotineiramente para solucionar problemas relativos à pesquisa operacional.

\subsection{Natureza da pesquisa operacional}

Pode-se observar que a pesquisa operacional está relacionada à pesquisa sobre operações. A PO tem sido aplicada nas mais diversas áreas, como manufatura, transporte, planejamento financeiro, na área militar e em serviços públicos. A PO se baseia no método científico. O método científico se inicia com a observação e formulação do problema, seguida da coleta de dados relevantes. O próximo passo é desenvolver um modelo científico, geralmente matemático, que pretende abstrair a essência do problema real. Então é formulada a seguinte hipótese: o modelo criado pode ser considerado uma representação satisfatória, de modo que as soluções obtidas pelo modelo também se tornem válidas para o problema real? Na próxima etapa são feitas as experimentações para testar essa hipótese e corrigir o modelo, 
etapa que é conhecida como validação. No entanto, a pesquisa operacional também trata da gestão prática da organização; logo, para ser efetiva, é necessário que leve a conclusões que ajudem os tomadores de decisão da organização (Hillier e Lieberman, 2006).

A pesquisa operacional trabalha com um conceito organizacional, tendo como objetivo encontrar a solução ótima para o problema, o melhor caminho a seguir (Hillier e Lieberman, 2006).

Gavira (2003) lista certas características inerentes à pesquisa operacional, como:

- A PO trabalha com problemas referentes ao modo de coordenar as operações de uma organização;

- Tem uma grande abrangência de aplicação nos negócios, nas indústrias e nos órgãos públicos;

- A pesquisa operacional usa o método científico;

- Tem um ponto de vista organizacional;

- Busca identificar a melhor solução possível, a solução ótima;

- Para a realização da PO é importante a utilização de equipes formadas por pessoas com diferentes experiências e habilidades.

\subsection{Vantagem do uso da pesquisa operacional}

Pela aplicação de um modelo de pesquisa operacional é possível encontrar uma solução ótima para um determinado problema, o que serve de auxílio ao tomador de decisão, que anteriormente tinha à sua disposição somente a intuição. Por esse motivo, a pesquisa operacional tem um impacto positivo em inúmeras organizações pelo mundo (Gavira, 2003).

Para comprovar a ampla aplicabilidade da PO, Hillier e Lieberman (2006) apontaram em seu livro alguns exemplos, como:

- A organização The Netherlands Rijkswaterstaat instituiu uma política nacional de gestão de recursos hídricos (em 1985) que gerou uma economia anual de US\$15 milhões de dólares; 
- A empresa Monsanto Corp. desenvolveu um otimizador de operação nas fábricas químicas (em 1985) que gerou uma economia anual de 2 milhões de dólares;

- A linha aérea United Airlines elaborou um modelo para programar turnos de trabalho nos balcões de reserva (em 1986) que gerou uma economia anual de 6 milhões de dólares;

- O departamento de polícia de São Francisco criou um otimizador para programar os cronogramas dos patrulheiros e simular suas rotinas em um sistema computadorizado (em 1989), que gerou uma economia anual de 11 milhões de dólares;

- A IBM desenvolveu um modelo para integrar os inventários em uma rede nacional de peças de reposição (em 1990), que gerou uma economia anual de 20 milhões de dólares, mais 250 milhões de dólares em decorrência de inventários menores;

- A Samsung desenvolveu métodos de redução de tempo de fabricação e níveis de estoque (em 2002), que geraram uma economia anual de 200 milhões de dólares.

\subsection{Técnicas de pesquisa operacional}

Em pesquisa não se utiliza somente uma técnica para resolver todos os modelos matemáticos, mas são o tipo e a complexidade do modelo matemático que determinam o meio de solução.

De acordo com Ecker e Kupferschmid (1988), na otimização em situações de incerteza destacam-se duas classes principais de métodos matemáticos usados na pesquisa operacional:

- Otimização - Programação linear, programação inteira, programação dinâmica, otimização em rede e programação não linear; 
- Probabilidade aplicada - Teoria das filas, modelos de estoque e simulação.

A técnica de otimização mais utilizada na PO é a programação linear, usada em modelos em que a função objetivo e as restrições são lineares. Outras técnicas de otimização são a programação inteira (em que as variáveis somente assumem valores inteiros), programação dinâmica (em que o problema é dividido em partes mais fáceis de resolver), otimização em rede (em que o problema é modelado como uma rede) e programação não linear (em que a função não é linear) (Taha, 2008).

Técnicas de PO, como modelos de filas e simulação, fazem uso de probabilidade aplicada. Essas técnicas determinam medidas de desempenho, como filas de espera, tempo médio de espera na fila, tempo médio para a conclusão da tarefa e taxa de utilização dos recursos. Os modelos de filas usam probabilidade e modelos estocásticos para estudar as filas de espera, enquanto a simulação conta com medições de desempenho, abstraindo e reproduzindo o comportamento do sistema real. A maior diferença entre os modelos de filas e a simulação é que os modelos de filas são unicamente matemáticos, o que limita a sua área de aplicação, enquanto a simulação é flexível e pode ser usada para estudar toda a situação de enfileiramento (Taha, 2008).

\subsection{Simulação na Pesquisa Operacional}

Esta seção aborda a utilização da simulação na área de pesquisa operacional. Com o crescimento dos estudos relacionados à pesquisa operacional, os problemas também aumentaram em complexidade, necessitando de técnicas mais aprimoradas para análise. A simulação foi desenvolvida para lidar com problemas de natureza estatística ou estocástica (Gavira, 2003).

Segundo Taha (2008), a simulação é o segundo melhor método de análise, ficando atrás somente da observação direta de um sistema real. A simulação é uma abstração do comportamento aleatório de um sistema com o objetivo de medir o desempenho, e ela é feita por meio de um computador. Ela tem como base a lógica do modelo computacional previamente programada, a qual permite coletar os dados necessários.

A simulação por ser uma ferramenta flexível, potente e intuitiva a sua utilização vem crescendo ao longo do tempo. Ela pode imitar um processo ou sistema inteiro, como também pode ser utilizada para análise de sistemas estocásticos. Para esses 
sistemas, o computador gera e registra os acontecimentos relativos aos eventos de rotina como se fosse uma operação real. O computador pode simular anos em pouco tempo, registrar o desempenho da operação simulada e simular diversos projetos alternativos, permitindo a avaliação e comparação desses projetos e facilitando as escolhas para o tomador de decisão (Hillier e Lieberman, 2006).

Um dos precursores da simulação existente hoje é a técnica Monte Carlo. Trata-se de uma forma de modelagem que estima parâmetros estocásticos ou determinísticos com base em uma amostra aleatória, assim iniciando a simulação probabilística. Entre as aplicações da simulação de Monte Carlo estão a avaliação de integrais múltiplas, a estimativa da constante $\pi$ e a inversão de matrizes (Taha, 2008).

No processo de simulação o comportamento do sistema pode ser medido ou ao menos estimado em distribuições de probabilidade, para cada um dos possíveis estados. As relações entre os elementos também são estimadas e construídas no modelo. Com a finalização do modelo, ele é ativado, simulando a operação real do sistema e registrando o seu comportamento. O modelo é ativado diversas vezes com configurações alternativas de operações do sistema, de acordo com o seu objetivo. Com base nesses diversos resultados, analisam-se os desempenhos e verifica-se a melhor solução. Apesar de não haver garantia de que a configuração resultará no melhor desempenho simulado devido ao erro estatístico, a configuração estará próxima à ideal se o experimento tiver sido projetado adequadamente.

\subsection{Conceitos Fundamentais Sobre O Método De Simulação}

Nessa seção é abordada a simulação de sistemas e é feita uma descrição dos principais conceitos usados neste estudo, como sistemas, modelos e filas.

\subsubsection{Sistemas}

Banks et al. (2005) definem um sistema como um grupo de instrumentos e materiais que são utilizados por alguma interação ou interdependência, com finalidade de alcançar um determinado objetivo. Um exemplo é a produção de carros: as máquinas, os componentes do carro e os trabalhadores na linha de montagem produzem o veículo. 
Um sistema pode ser afetado pelo ambiente externo, por esse motivo é necessário criar limites entre o sistema e o ambiente para modelar aquele, com esses limites variando de acordo com o objetivo do estudo (Banks et al., 2005).

\section{Componentes do sistema}

Segundo Banks et al. (2005), para entender e analisar um sistema há alguns termos que necessitam ser esclarecidos. Esses termos são:

- Entidade: significa o objeto de interesse no sistema;

- Atributos: são as propriedades da entidade;

- Atividade: representa as atividades das entidades;

- Eventos: um momento no qual pode ocorrer uma mudança no sistema;

- Variáveis: o estado do sistema descrito por variáveis, relativas ao objeto de estudo.

Assim, se o objeto de estudo fosse o sistema de um banco:

- Os clientes seriam as entidades;

- O balanço das suas contas o atributo;

- Os depósitos a atividade;

- A chegada ao banco o evento;

- O número de clientes aguardando seriam as variáveis.

\section{Sistemas discretos e contínuos}

Um sistema pode ser discreto ou contínuo. Um sistema discreto é aquele em que o estado das suas variáveis muda instantaneamente no tempo. Exemplo: um banco tem um sistema discreto, pois sua variável muda repentinamente quando um cliente chega. Um sistema contínuo é aquele em que as variáveis mudam de estado continuamente ao longo do tempo. Exemplo: o movimento de um avião no ar, em que 
tanto sua posição quanto sua velocidade estão variando de acordo com o tempo. São poucos os sistemas que são totalmente contínuos ou totalmente discretos, mas sempre há um tipo dominante em cada sistema, o que possibilita a classificação (Law e Kelton, 1991).

Banks et al. (2005) demonstram, nos gráficos (1 e 2) a seguir, a variável em um sistema discreto e a variável em um sistema contínuo. O exemplo do sistema discreto é o banco em que a variável muda conforme os clientes chegam ao sistema e saem dele. Para o sistema contínuo foi considerada a quantidade de água em uma determinada barragem, antes da chuva, durante e após esta.

Gráfico 1 -Variável em um sistema discreto

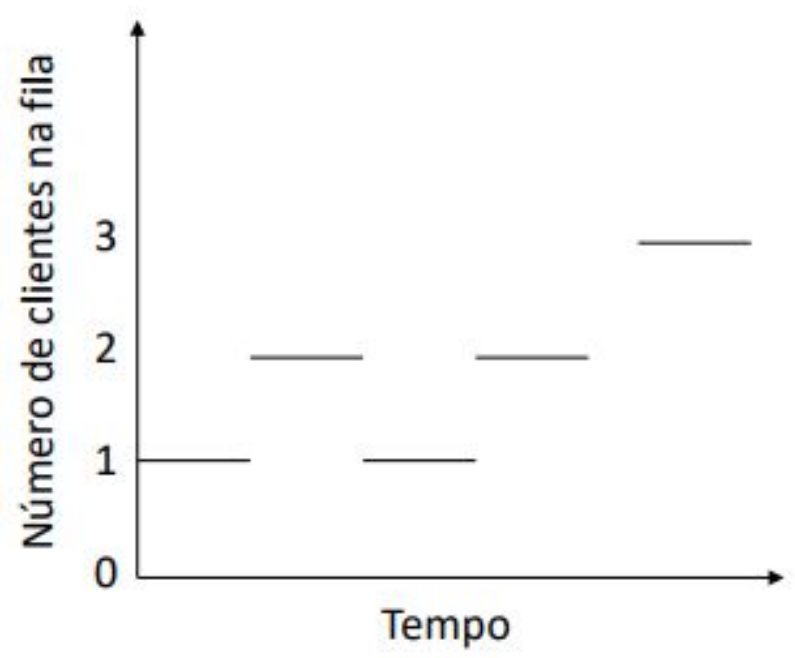

Fonte: (Banks et al., 2005). 
Gráfico 2 - Variável em um sistema contínuo

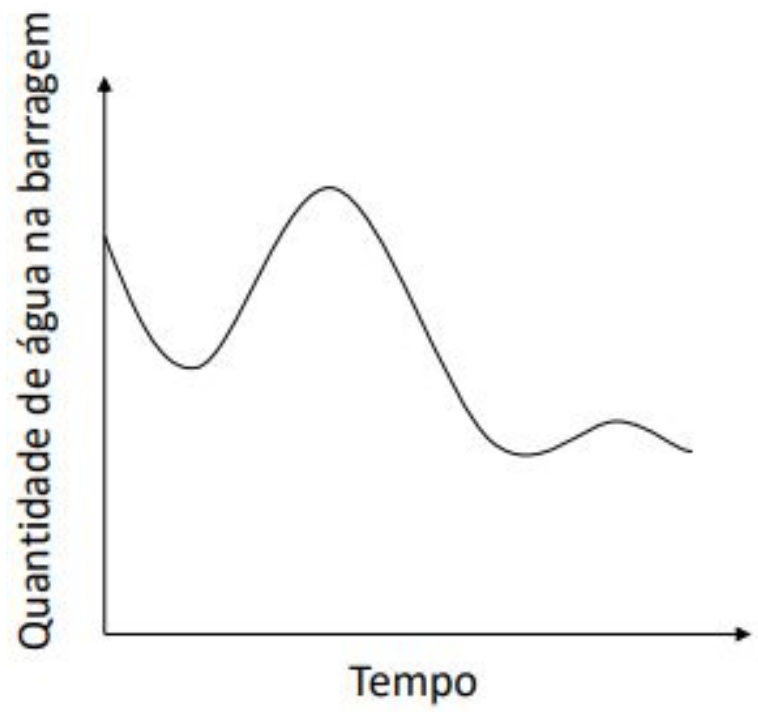

Fonte: (Banks et al., 2005).

\section{Tipos de estudos de sistema}

De acordo com Law e Kelton (1991), é preciso que sejam estudados os sistemas com o objetivo de se verificarem algumas hipóteses acerca das relações entre os diversos componentes em um sistema ou predizer a performance deste em novas condições. Law e Kelton (1991) distinguiram algumas formas de estudar um sistema, que são apresentadas na figura 3 e explicadas a seguir. 
Figura 3 - Tipos de estudo do sistema

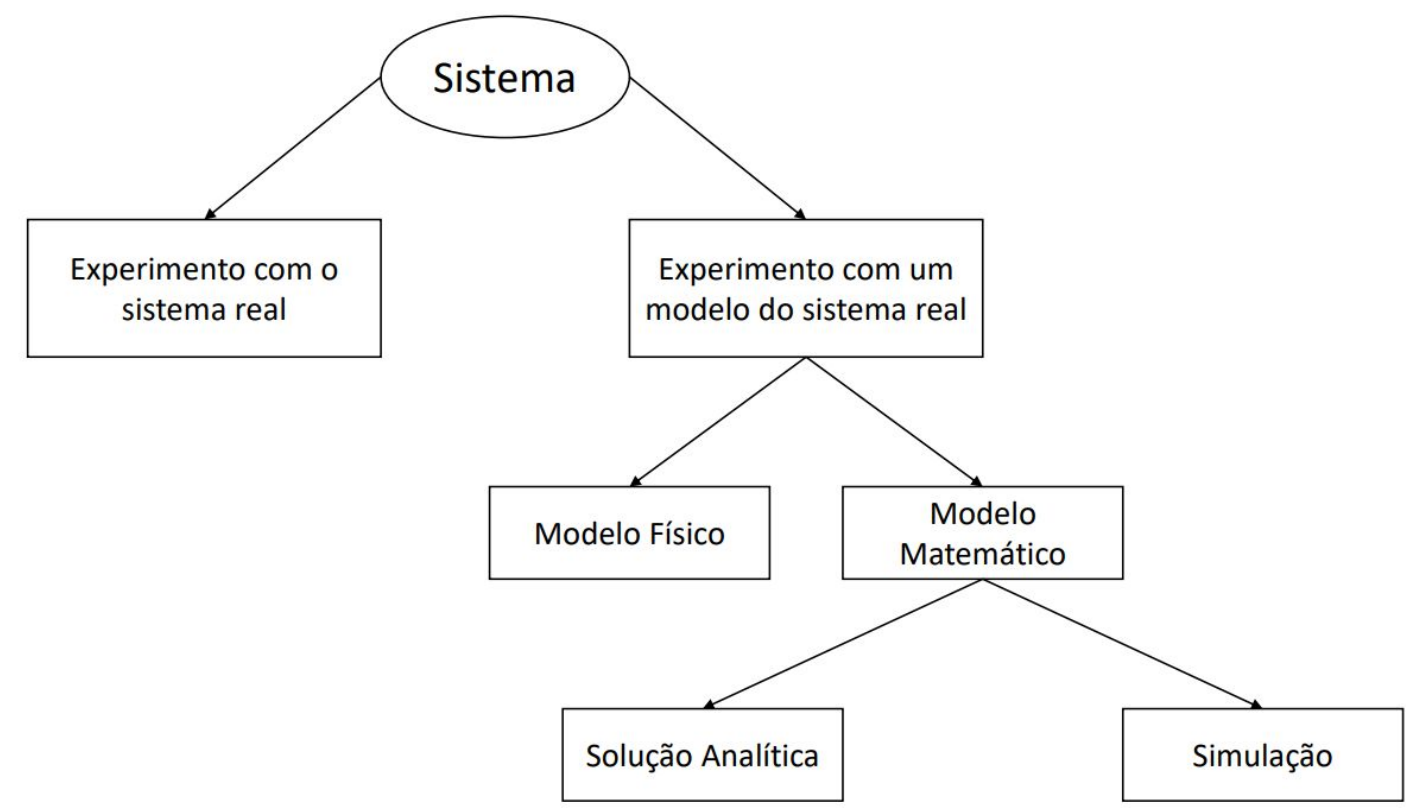

Fonte: Law e Kelton (1991).

- Experimento com o sistema real ou experimento com um modelo do sistema: só é possível se o custo for viável para alterar fisicamente o sistema e operá-lo sob novas condições. No entanto, isso raramente ocorre, pois esse experimento é caro e é difícil manter o sistema estável. Por esse motivo, geralmente é construído um modelo que represente o sistema. O objetivo é estudá-lo e identificar alternativas de mudanças para então escolher a melhor opção.

- Modelo físico ou modelo matemático: os modelos físicos são réplicas com dimensões reduzidas. Os modelos matemáticos utilizam símbolos em lugar de dispositivos físicos, e neles o sistema é representado por relacionamentos lógicos e quantitativos, que são alterados para se observar como o sistema responde.

- Solução analítica ou Simulação: construído o modelo matemático, o próximo passo é examiná-lo para verificar como ele pode ser usado para responder às hipóteses de interesse sobre o sistema. Se o modelo for 
simples o suficiente para trabalhar com as relações e quantidades de forma exata, aplica-se a solução analítica. Da mesma forma, se a solução analítica for viável e eficiente computacionalmente, ela torna-se a abordagem mais adequada. Entretanto, diversos sistemas são muito complexos, o que dificulta a abordagem analítica. Nesse caso escolhe-se o modelo de simulação, com a finalidade de entender como as entradas e variáveis afetam as saídas e medidas de desempenho.

\subsubsection{Modelo do sistema}

O item anterior abordou o funcionamento de um sistema. Pela análise de um sistema é possível entender as relações entre seus componentes ou testar hipóteses sobre ele. Para tanto, é criado um modelo que funciona como uma representação do sistema e utilizado como objeto de estudo. Na maioria dos estudos somente é necessário considerar os aspectos do sistema que afetam diretamente o problema que está sendo analisado. Esses aspectos são representados em um modelo, que é uma simplificação do sistema, mas esse modelo deve ser suficientemente detalhado para permitir a validação das conclusões que são investigadas. Por esse motivo, um sistema pode dispor de mais de um modelo para testar cenários diferentes (Banks et al., 2005).

\section{Modelo de simulação}

Neste trabalho o modelo utilizado foi o de simulação discreta. O sistema de simulação discreta é aquele no qual as variáveis mudam somente em pontos determinados no tempo. Os modelos de simulação são analisados por meio de métodos numéricos. Os métodos numéricos consistem em procedimentos computacionais para resolver o modelo matemático. No caso da simulação os modelos são rodados em vez de resolvidos, ou seja, a abstração do sistema real é desenvolvida com base em hipóteses, observações de dados coletados/analisados e estimativas das medidas de desempenho (Banks et al., 2005). 


\section{A SIMULAÇÃO DE SISTEMAS}

Este capítulo faz uma revisão bibliográfica com foco em modelos de simulação em terminais portuários.

Segundo Gavira (2003), as empresas têm se restruturado para tomar decisões mais complexas da melhor forma possível, utilizando o método cientifico. Esse processo permite que elas acompanhem as mudanças de cenário, suprindo as necessidades do mercado consumidor. Um método que permite utilizar a intuição, a lógica matemática, o empirismo e a experiência dos profissionais é a simulação. Com o desenvolvimento da tecnologia as ferramentas têm se tornado vez mais acessíveis, facilitando a utilização deste método.

\subsection{Natureza da simulação}

Simulação, de acordo com Banks et al. (2005), é a construção de um modelo que se equipare a um sistema do mundo real. A simulação pode ser feita pelo computador ou em meio físico, com a finalidade de criar uma história artificial, verificando o comportamento do sistema ao longo do tempo, para inferir características operacionais do sistema real. Os modelos criados adotam certas suposições juntamente com o sistema, as quais são descritas em forma de relacionamentos matemáticos ou lógicos. O modelo é então desenvolvido e validado, podendo ser usado para verificar diversos tipos de alterações, prevendo assim o impacto destas no desempenho dos sistemas.

Uma definição muito semelhante foi dada por Law e Kelton (1991). Segundo eles, a simulação é a técnica de usar computadores para imitar operações ou processos do mundo real. Para construir o modelo de simulação é necessário um conjunto de suposições sobre como o sistema real funciona. Se essas suposições forem simples, é possível utilizar métodos matemáticos para obter as informações necessárias. No entanto, a maioria dos sistemas do mundo real é complexa demais para que isso funcione, e nesse caso deve ser utilizada a simulação. Na simulação, o computador avalia numericamente um modelo e os dados são coletados para estimar as medidas de desempenho do sistema. 


\subsection{Quando a simulação não é uma ferramenta adequada}

No entanto, antes de se fazer uso da simulação para resolver um problema, deve-se entender o que não é simulação e o que ela não pode fazer. Chwif e Medina (2014) esclarecem esses dois aspectos:

- A simulação não prediz o futuro: a simulação pode prever um comportamento de um sistema com base nos dados de entrada em conjunto com uma série de premissas;

- A simulação não é um modelo matemático: uma forma analítica direta, como um conjunto de equações, não gera os resultados relativos ao comportamento do sistema;

- A simulação não é necessariamente uma ferramenta de otimização: simulação é uma ferramenta de análise de cenários;

- A simulação não substitui o pensamento inteligente: a simulação auxilia na tomada de decisão, mas não pode substituir o ser humano no processo;

- A simulação não é utilizada somente como último recurso: a simulação é, atualmente, uma das técnicas mais utilizadas na Pesquisa Operacional;

- A simulação não se aplica a todos os problemas: a simulação se adapta bem a uma determinada classe de problemas.

Além disso, Banks e Gibson (1997) listam dez regras para identificar quando a simulação não é uma ferramenta apropriada a ser utilizada:

- A simulação não deve ser utilizada quando o problema puder ser resolvido pelo uso do senso comum;

- Quando um problema puder ser resolvido analiticamente, a simulação não será uma ferramenta adequada;

- A simulação não deve ser usada quando a realização de experimentos diretos puder ser efetuada facilmente; 
- Quando não existirem recursos financeiros suficientes para a realização da simulação;

- Quando o tempo para realizar a simulação não satisfizer a expectativa;

- A simulação não é recomendada se os dados não estiverem disponíveis e não puderem ser estimados, pois ela precisa de dados;

- Para se fazer uma simulação, as expectativas têm que ser racionais;

- Se o comportamento do sistema for muito complexo ou não puder ser definido, a simulação não será apropriada.

\subsection{Quando a simulação é uma ferramenta adequada}

Banks et al. (2005), em seu livro, informam quando a simulação é uma ferramenta apropriada a ser utilizada:

- Quando permite o estudo das interações de sistemas complexos e experimentações com estas;

- Quando o ambiente ou a organização passam por mudanças e isso pode ser simulado, conseguindo-se prever o efeito dessas mudanças;

- Quando, ao se construir um modelo de simulação, o conhecimento gerado pode ser importante para trazer à tona sugestões de melhorias do sistema;

- Para se obter informações sobre as variáveis mais importantes e como elas interagem entre si;

- Como um método pedagógico para reforçar ou verificar uma solução analítica;

- Para testar novas políticas antes de serem implementadas, a fim de prever os efeitos provocados por elas;

- Para determinar os requisitos de uma máquina, simulando os diferentes recursos que ela poderá exigir; 
- Como modelo projetado para treinamento, de forma a possibilitar um aprendizado com custo reduzido e sem interrupção das operações normais (por não exigir uso de espaço físico);

- Para exibir a animação de um sistema em operação simulada a fim de visualizar o plano de ação;

- Para tratar de sistemas complexos.

A simulação pode ser aplicada em diversas áreas. Law e Kelton (1991) apresentam alguns problemas para os quais a simulação foi uma ferramenta adequada, a seguir:

- Projetar e analisar sistemas de manufatura;

- Avaliar novas táticas militares;

- Determinar as políticas de pedidos para um sistema de estoque;

- Projetar sistemas de comunicação;

- Projetar e operar instalações de transporte, como rodovias, aeroportos e portos;

- Avaliar projetos para organizações de serviços, como hospitais, restaurantes e correios;

- Analisar sistemas financeiros.

\subsection{Método de condução para o projeto de simulação}

Law e Kelton (1991) desenvolveram uma estrutura para administrar as etapas de um trabalho de simulação computacional.

a) Formulação do problema e planejamento do estudo - Todo estudo deve começar estabelecendo um objetivo claro e os pontos específicos a serem considerados, definindo também as alternativas a serem testadas e os pressupostos a serem adotados. 
b) Coleta de dados e formulação do modelo conceitual - As informações e os dados coletados devem esclarecer os procedimentos do sistema e definir as distribuições de probabilidade para as variáveis do modelo.

c) Validade - Consiste em verificar se o modelo é válido tanto no modelo conceitual quanto nas coletas de dados.

d) Construção e verificação de um programa computacional - Consiste em escolher um software de simulação e transformar o modelo conceitual em um programa computacional. Após a finalização do programa, é realizada uma verificação da existência de erro de lógica e sintaxe.

e) Replicação-piloto - Os ciclos de replicação são feitas para validar o programa na fase seguinte.

f) Validação - A validação é adotada para averiguar se as rodadas-piloto têm como saída informações que refletem o sistema real.

g) Planejamento do experimento - Como a simulação tem uma natureza estocástica, ela apenas estima o comportamento do sistema para determinados parâmetros. Por isso, é necessário planejar o experimento definitivo. É importante salientar a relevância da definição do período, para que os parâmetros estejam em condições apropriadas para a simulação daquele instante. Esse intervalo de tempo é conhecido como aquecimento.

h) Realização de rodadas produtivas - Considerando-se os parâmetros estabelecidos na etapa anterior, fazem-se as rodadas para levantamento dos resultados relativos aos cenários escolhidos.

i) Análise dos dados de saída - Técnicas estatísticas devem ser utilizadas para analisar os dados de saída. Nos casos de várias alternativas, escolhe-se a melhor opção. 
j) Documentação, apresentação e implementação - Como os projetos de simulação quase sempre são usados novamente, é necessário documentar todo o projeto, a fim de poder utilizá-lo no futuro. Para que o estudo seja um sucesso, é preciso que ele seja apresentado e o resultado das análises seja implementado.

A figura 4 ilustra a sequência de etapas descritas. 
Figura 4 - Estudo de simulação

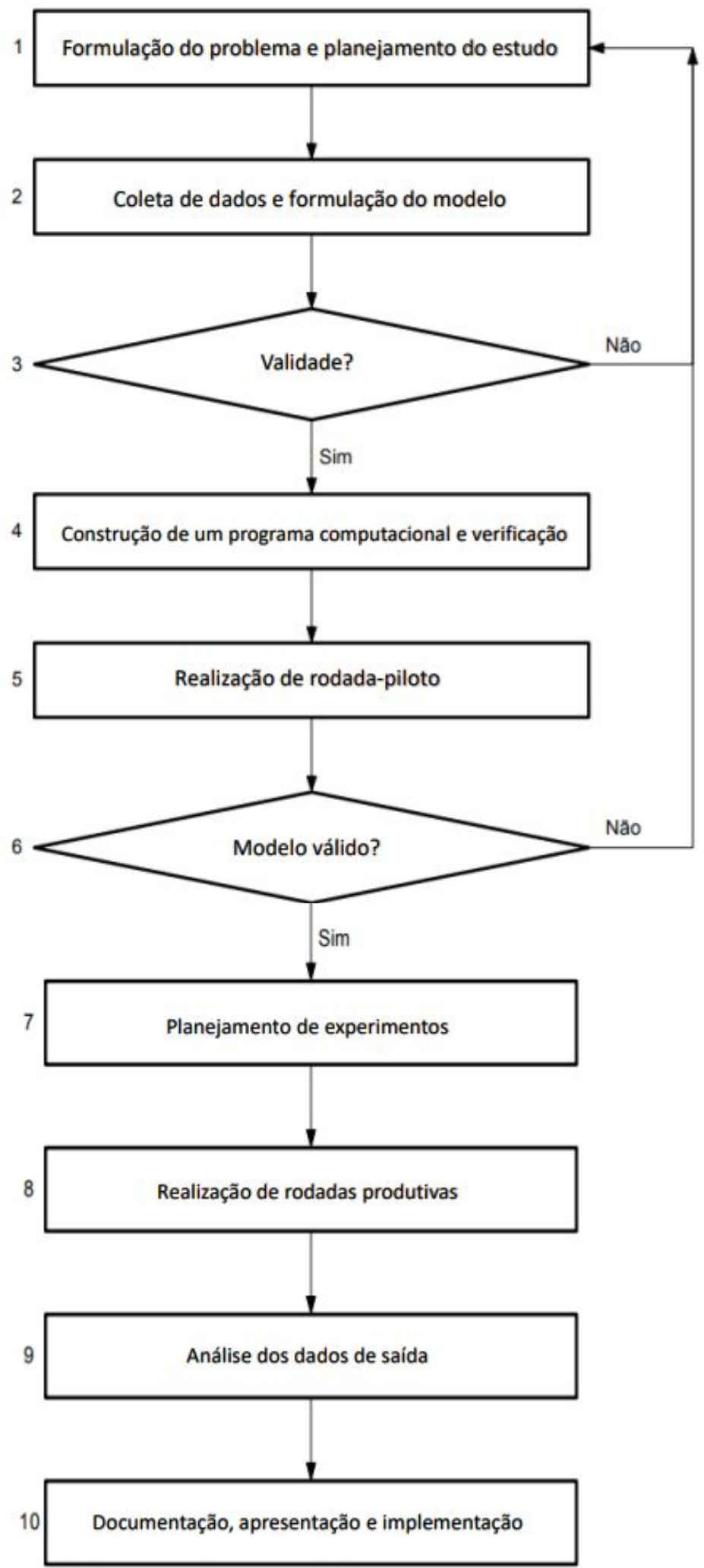

Fonte: Neto (2016). 


\subsubsection{Vantagens e Desvantagens da Simulação}

A simulação traz várias vantagens se comparada com outros métodos analíticos ou experimentais. Pegden et al. (1995) apontam as seguintes vantagens da simulação:

- Depois de já criado o modelo, pode-se utilizá-lo diversas vezes para avaliar projetos e políticas propostas;

- Permite a análise de longos períodos em um curto espaço de tempo;

- O desenvolvimento do modelo de simulação ajuda a distinguir os parâmetros controláveis daqueles que não são controláveis e estudar a influência de cada um deles sobre o sistema;

- Hipóteses sobre certos fenômenos que acontecem podem ser testadas para obter confirmação.

Law e Kelton (1991) listam as seguintes desvantagens para a simulação:

- Os modelos de simulação devem ser rodados várias vezes para prever a performance do sistema devido à natureza estocástica destes;

- A simulação é dependente da validade do modelo desenvolvido. Se o modelo não representa o sistema ou se os dados de entrada estão incorretos, o estudo detalhado se torna ineficaz, impossibilitando a análise dos dados de saída e consequentemente a solução do problema;

- A simulação não otimiza o sistema; apenas testa as alternativas sugeridas pelos usuários. 


\subsubsection{Componentes de um sistema de Simulação}

Destaca-se que existe uma diferença entre: os componentes do sistema e os dos componentes do sistema de simulação, visto que os componentes do sistema de simulação são mais específicos.

Para entender e analisar um sistema de simulação, segundo a empresa Paragon alguns termos devem ser definidos:

- Entidade: é o objeto de interesse no sistema. Representa um objeto que dentro do sistema se move e interage com os recursos

- Variáveis: são valores do sistema, acessíveis a qualquer momento no modelo. As variáveis determinam o estado do sistema como um todo e não as características individuais de cada entidade.

- Variáveis de estado: fornecem informações do que está acontecendo no sistema num determinado período.

- Atributo: propriedade de uma entidade. O valor de um atributo pode ser alterado ao longo do caminho da entidade. Lembrando que quando se deseja alterar o valor de todas as entidades deve-se utilizar variáveis e não atributos.

- Recurso: são objetos fixos no sistema e são utilizados pelas entidades. Representando as estruturas do sistema como máquinas e postos de trabalho.

- Tempo simulado e tempo de simulação: o primeiro refere-se ao tempo real, já o segundo refere-se ao tempo necessário para execução de uma simulação.

- Filas: são acúmulos de entidades geradas por alguma limitação na capacidade do recurso.

- Eventos: acontecimentos (programados ou não) que quando ocorrem provocam uma mudança de estado em um sistema. 


\subsection{Simulação de sistemas em terminais portuários}

Wright et al. (1983), em seu artigo, realizaram uma análise do fluxo de rede para investigar possíveis melhorias a longo prazo no transporte de grãos para o porto, em um estado brasileiro. Algumas melhorias analisadas foram: construção de uma nova trilha nas subseções da linha Bley-Paranaguá, extensão da linha sul de Guarapuava para Cascavel, construção de uma linha de Bley para Gutierrez e construção ou reparo das linhas entre Gutierrez/Guarapuava, e Gutierrez/Ponta Grossa. Esse artigo mostrou que a análise por simulação pode ser efetivamente usada para estudar o impacto de investimentos em transporte alternativo e de sequências de investimentos. Um exemplo de resultado de análise de sequência de investimento foi: antes da extensão da linha sul de Guarapuava para Cascavel, deve-se melhorar a ligação de Bley para Guarapuava.

Park e Noh (1987) desenvolveram um modelo de simulação com o método Monte Carlo, com o objetivo de simular a capacidade econômica futura do porto para atender à demanda projetada de carga. O modelo determinou os efeitos causados pela expansão da capacidade do porto e avaliou os impactos da mudança na infraestrutura sobre a economia portuária. Foi determinado que o impacto econômico que ocorreria caso a expansão fosse realizada poderia ser de US\$19.210.482 por ano.

Koh et al. (1994) desenvolveram um modelo de simulação para visualizar as operações portuárias de contêineres, com a finalidade de permitir ao tomador de decisão avaliar o desempenho dessas operações, possibilitando assim a análise de alterações nas operações antes de serem executadas. Isso resultou em menos alterações nas operações em curso, menos conflitos por recursos e uma taxa de transferência melhor para toda a operação portuária, gerando uma melhora nas operações portuárias e na previsão de desempenho do porto.

Thiers e Janssens (1998) criaram um modelo detalhado do tráfego marítimo em um rio, incluindo lógica de navegação, marés e planejamento de eclusas, com a finalidade de investigar os obstáculos do cais desse rio ao acesso ao porto da Antuérpia, na Bélgica. $O$ acesso a esse porto é feito por meio de eclusas que conectam o rio às docas. Os experimentos desse modelo foram baseados nas medições da época em que o artigo foi escrito e nas previsões de tráfego. O modelo foi construído de tal forma que pode ser reutilizado e se estender a futuras decisões sobre a infraestrutura ou sobre projetos de manutenção. 
Kia et al. (2002), em seu artigo, verificam a capacidade de um porto através de uma nova abordagem de simulação computacional, avaliando o desempenho das técnicas de manuseio e o seu impacto na capacidade de um terminal de contêineres. O modelo detectou a área de congestionamento do terminal e comparou dois sistemas operacionais, gerando uma economia para a expansão do porto. No artigo foi proposto um método de carregamento dos navios pela interface ferroviária combinada com o centro de distribuição. Foi estimado que esse método reduz o tempo de carregamento do navio em 8\%, gerando uma economia de aproximadamente US\$ 2.7 milhões por ano.

Luo e Grigalunas (2003), em seu artigo, mostram o desenvolvimento e a aplicação de um modelo de simulação de demanda de transporte espacial, econômico e multimodal para os principais portos de contêineres dos EUA. Após a validação do modelo, ele é utilizado para estimar: a demanda anual de serviços de transportes de contêineres, as áreas de mercado atendidas pelos portos, o impacto na demanda portuária e a concorrência entre portos relacionada às mudanças hipotéticas nas taxas dos portos.

Demirci (2003) utilizou o modelo de simulação para identificar os pontos de gargalo sob condições de sobrecarga. Com base nos resultados obtidos por meio do modelo de simulação, verificou-se que os pontos de gargalo mais críticos eram os de carregamento e descarregamento de veículos. Uma estratégia de investimento foi desenvolvida a partir desse modelo para balancear a carga no porto.

Cortés et al. (2007) elaboraram uma simulação do processo de transporte de carga no porto de Sevilha, na Espanha. A simulação se inicia no movimento de transição entre o rio e o mar e termina com os navios chegando ao porto, onde ocorre o processo de carga e descarga. Ela considera todos os tipos de carga existentes no porto, como: contêineres, cereais, cimento, sucata, ferro, aço e fertilizantes. Após o teste de vários cenários, constatou-se que a infraestrutura portuária permite lidar com os fluxos logísticos do porto e com momentâneas dificuldades no tráfego de contêineres. No entanto, para aumentar o volume dos negócios é necessário investir na infraestrutura, na qual deve ser incluída a dragagem do rio e substituição da eclusa por uma de maiores dimensões, de modo a permitir a chegada de embarcações maiores.

Julia e Botter (2009) desenvolveram um modelo de simulação para dimensionar um sistema integrado pátio-porto. Esse modelo permitiu a análise de diversos resultados, tal como a taxa de ocupação de berços, a taxa de ocupação de 
equipamentos, o tempo em fila e a taxa global de carregamento, além de apresentar cenários para expansão desse sistema pátio-porto e traçar uma comparação entre cada cenário.

Brito (2009) utilizou a modelagem e a simulação para propor um terminal regulador de contêineres na região de Cubatão. Esse terminal teria a finalidade de manter o equilíbrio entre os fluxos de saída e de entrada de contêineres. Esse autor também apresentou diversos cenários, descrevendo as possíveis configurações da operação desse terminal, e identificou os principais problemas gerados pela criação desse terminal regulador.

Neves e Ignacio (2010) utilizaram os softwares de simulação Simul8 e a sua ferramenta Stat::Fit para fazer uma análise dos parâmetros nos estudos de simulação em terminais portuários. Os modelos de simulação de sistemas de carga e descarga requerem parâmetros de confiabilidade. Nesse sentido, esse estudo demonstrou como esses softwares auxiliam na determinação das estatísticas básicas das variáveis relacionadas a falhas e no ajustamento de distribuições.

Arango et al. (2011), em seu artigo, estudaram o problema de alocação de berços para contêineres no porto de Sevilha. O artigo aborda os problemas relativos ao planejamento dessa alocação usando a simulação e otimização. Com a finalidade de minimizar o tempo total de serviço de cada navio, foi utilizado o software Arena para a simulação e uma heurística baseada em um algoritmo genético para a otimização. Verificou-se, através dos experimentos computacionais, que o modelo "do primeiro que chegar é o primeiro a ser atendido" era a melhor estratégia de gerenciamento de berços, reduzindo o tempo dos navios nos berços em $14 \%$.

Além dos trabalhos citados, Hassan (1993), em seu artigo, fornece uma visão geral da simulação computacional utilizada como suporte à decisão, auxiliando e avaliando as atividades portuárias. Ele relacionou diversos trabalhos de simulação em portos, e alguns são descritos a seguir:

- Collier (1980) apresenta um estudo de um porto como sistema. Trata-se de um sistema portuário que considera a chegada de carga por meio da rodovia ou ferrovia, o armazenamento de mercadoria, os meios de manuseio da mercadoria nas instalações e no cais do porto. $\mathrm{O}$ artigo descreve os procedimentos de coleta de dados, além da construção e 
validação do modelo, considerados satisfatórios para o Reino Unido. Em seguida, o autor demonstra os princípios da construção de simulação que permitem examinar os efeitos de fatores como: filas de caminhões, atrasos no transporte, estoque de carga e políticas de manutenção.

- Wadhwa, L. C., James, M. K. e Vincent (1980) desenvolveram um modelo de simulação que incorpora programas estatísticos, com a finalidade de recolher os dados brutos do porto, analisá-los e fornecer as entradas necessárias para o modelo. Esse modelo de simulação tem foco em navios e operações de carga. Pela aplicação do modelo em dois portos australianos, foram produzidas estatísticas sobre os tipos de navios, resumo dos indicadores de desempenho, de produtividade da mão de obra/equipamentos e estatísticas sobre instalações de atracação.

- Radaceanu (1985) demonstra o conceito do modelo de simulação de um tráfego ferroviário referente à operação de portos. Esse modelo tem a finalidade de melhorar a gestão do tráfego ferroviário, sendo usado como parte do sistema de gerenciamento do porto. Pode ser empregado para administrar diversas alternativas de prioridade, distribuição de hora de chegadas e tempos de operação do trem.

- McCall (1989) descreve detalhadamente uma simulação de eventos discretos pelo método de Monte Carlo, com o objetivo de analisar a produtividade de terminais de petróleo utilizados pela reserva estratégica de petróleo do departamento de energia do Estados Unidos. O modelo foi feito em FORTRAN IV para computadores pessoais. A entrada do modelo consiste na descrição detalhada da configuração física dos terminais de petróleo, das características de divergência, das informações sobre a frota e a barcaça dos navios, dos dados do tráfego de navios, do clima esperado e das características do canal de embarque. O modelo simula a programação dos navios, a distribuição do berço, os conflitos de 
embarcação no canal de embarque, o uso da área de retenção dos navios, os atrasos aleatórios no processamento da embarcação e aqueles ocorridos devido a restrições (físicas, climáticas e de horário) do canal.

- Collier e Litherland (1979), em seu modelo, tentam diminuir os custos envolvidos no carregamento dos navios, reduzindo ou eliminando os atrasos da operação. $\mathrm{O}$ artigo foca em descrever como a modelagem de casualidade pode ser usada para isolar as causas de atraso mais significativas e mostra o efeito que a programação tem sobre o tempo subsequente perdido nas operações de manipulação. De dois portos do Reino Unido foi obtida uma lista dos atrasos no manuseio de uma carga específica. Utilizando-se a análise de regressão, foram examinados nove navios e seus respectivos atrasos, e dessas análises foram depreendidas conclusões relativas à melhora da produtividade.

- Raman e Ramkumar (1988) desenvolveram um modelo de simulação para análise do tempo de espera de navios e da ocupação de berços. O modelo investiga a sensibilidade do tempo de espera do navio, a ocupação do berço em relação à duração da detenção no berço, o tempo perdido devido à restrição de ambiente e o aumento do número de embarcações que fazem escala no porto. Descobriu-se que, com a melhora dos métodos de manuseio de carga e o aumento da mão de obra para manutenção, obtém-se uma redução do tempo de espera de navios e da ocupação de berços.

- Sheikh et al. (1987) descreveram um modelo de simulação que foi construído para ajudar a determinar o número de berços dos quais um porto precisaria em alguns anos. O porto trabalha com vários tipos de carga de entrada e saída, utilizando berços especializados e gerais. A finalidade do modelo de simulação era fornecer estimativas de tempo de espera de navios para diversos níveis de serviço e demanda no porto, 
correspondentes às diferentes taxas de manuseio e diferentes níveis de tráfego.

- Soros e Zador (1977) propuseram um modelo de simulação que contempla o planejamento portuário, programando dois grupos de simulação que podem funcionar em conjunto ou separadamente. O primeiro simula a operação de um complexo portuário e o segundo simula a operação dos sistemas de manuseio de materiais conectados ao porto. Essas simulações são utilizadas para prever situações relacionadas à seleção do número/tamanho/capacidade dos berços, da capacidade do equipamento de manuseio de materiais, da capacidade do sistema de transporte e para a determinação dos requisitos de estoque. A análise pode esclarecer o impacto das mudanças de uma área em outra ou no sistema geral, avaliando alternativas de modificação em qualquer parte do sistema.

- Park e Noh (1987) apresentam um modelo de simulação de expansão portuária orientada ao usuário, em que é determinada a capacidade econômica futura do porto para atender à demanda projetada. O modelo se divide em duas partes: uma simulação de impacto físico e uma simulação de impacto econômico. A primeira parte simula os efeitos causados pela expansão da capacidade portuária. A segunda parte avalia o impacto de mudanças na capacidade portuária na economia do porto. O modelo de simulação (após a validação) foi aplicado no porto de Mobile, Alabama (EUA).

- Frankel et al. (1973) discutem o uso de métodos de análise e simulação de sistemas para auxiliar na escolha entre instalações portuárias offshore. Também são apresentadas otimizações de investimento, de custos e de alocação de recursos.

- Collie (1975) propôs o uso de um aparelho de simulação de incidentes variáveis para proporcionar aos estagiários uma experiência útil em 
gerenciamento de porto dentro dos limites do laboratório. O artigo trata de um caso específico relacionado ao manuseio de carga, em que o aparelho deve ser capaz de expressar as respostas resultantes de decisões tomadas pelos participantes. Os dados da simulação, quando analisados, podem fornecer informações valiosas para a tomada de decisões no estado real. Concluiu-se que o aparelho foi útil no desenvolvimento da conscientização da gerência sobre as disciplinas envolvidas nas operações portuárias. $\mathrm{O}$ modelo também permite retratar graficamente o efeito dos atrasos, podendo ser testadas algumas flexibilizações de políticas alternativas.

- Bressman et al. (1978) utilizaram uma técnica para incorporar as incertezas no planejamento financeiro e na avaliação de uma proposta de investimento. As entradas e saídas de caixa anuais futuras foram simuladas e usadas para avaliar um projeto em termos de viabilidade financeira geral.

Yakimov et al. (2017) fornecem uma descrição de 13 sistemas de modelagem estruturada e de simulação: AnyLogic, Arena, Bizagi Modeler, Business Studio, Enterprise Dynamics, ExtendSim, FlexSim, GPSSW, Plant Simulation, Process Simulator, Rand Model Designer, Simio and Simul8. O artigo tem como finalidade auxiliar os usuários convencionais na seleção dos sistemas de modelagem estruturada e de simulação que existem no mercado. Ao se calcular a diferença média entre o modelo analítico e o modelo de simulação em porcentagem, chegou-se aos seguintes resultados: Simul8 $(0,633)$, Process Simulator $(1,004)$, GPSSW $(1,020)$, Enterprise Dynamics (1,534), ExtendSim (1,700), Bizagi Modeler (1,798), Simio (1,978), Rand Model Designer (2,211), Plant Simulation (2,326), AnyLogic $(2,660)$, Arena $(2,830)$, FlexSim (3,673), Business Studio $(3,805)$.

Terminais de granéis são usados em todo o mundo para lidar com grandes quantidades de granéis. Estes são transportados dentro do terminal através de rotas de transportadores de correia interconectados. Devido a várias fontes de incerteza, como os atrasos de navios, de trens e distúrbios em equipamentos, os operadores têm 
dificuldade na seleção das rotas dos grãos, baseando-se somente na experiência. Para remediar essa situação, Van Vianen et al. (2012) escreveram um artigo que teve como objetivo a seleção de rotas para transporte dos grãos. Nesse artigo, um sistema de apoio à decisão é proposto para ajudar o operador a tomar a melhor decisão. Esse sistema é chamado "Planejador Dinâmico" e consiste em um modelo que simula a dinâmica do terminal. Dentro desse modelo de simulação primário, um segundo modelo simula e propõe rotas. O "Planejador Dinâmico" pode ser uma ferramenta útil para auxiliar os tomadores de decisão na seleção de rotas ou apresentar rotas alternativas no caso de avaria em um transportador ou máquina. Experimentos práticos realizados para avaliar o desempenho do "Planejador Dinâmico" permitiram constatar que, geralmente, as rotas simuladas correspondem às rotas selecionadas pelo operador e, em alguns casos, há sugestões de rotas alternativas.

Netto et al. (2015) expuseram em seu artigo uma metodologia que utilizava a simulação de eventos discretos para a determinação da capacidade de um porto a partir dos níveis de serviço. O modelo de simulação demonstrou estratégias que poderiam ser implementadas para aumentar a capacidade do porto naquele momento, de 39.5 milhões de toneladas/ano para 64,2 milhões de toneladas/ano, com os recursos com maior índice de utilização sendo os berços, que seriam $85 \%$ preenchidos.

Zampirolli e Botter (2017) desenvolveram um modelo de simulação de eventos discretos que analisou diversos cenários, visando aumentar a capacidade de um terminal portuário de minério de ferro. Foi proposta a troca de mix de produtos por um único produto, o que se mostrou uma alternativa viável para o aumento da capacidade do terminal, possibilidade que foi comunicada ao tomador de decisão. O modelo criado também possui flexibilidade para a criação de novos cenários.

Dragović et al. (2017) apresentam uma revisão da literatura sobre a aplicação de modelos de simulação no desenvolvimento de portos. Com o foco em terminais de contêineres, este artigo tem o intuito de analisar o uso de modelos de simulação relacionados a portos e avaliar sua contribuição na construção do conhecimento de pesquisa necessário, promovendo interfaces sustentáveis de navios-portos e cadeias de transporte de carga. Constatou-se que os modelos de simulação têm sido cada vez mais utilizados no desenvolvimento de portos, e a tendência observada foi o emprego de ferramentas de simulação que possam oferecer resultados mais realistas para garantir que a modelagem de simulação ofereça soluções tangíveis às empresas. $O$ modelo de simulação tem capacidade de reproduzir soluções rápidas e confiáveis para problemas relacionados a portos, e a simulação tem sido uma ferramenta de apoio à 
decisão muito importante para desenvolvedores de portos, com sua eficácia tendo sido demonstrada na área de operações portuárias. Nesse âmbito, a simulação de eventos discretos continua sendo uma das técnicas mais utilizadas, a despeito da introdução de novas técnicas, como modelagem baseada em agentes, modelagem baseada em rede, entre outras.

Cimpeanu et al. (2017) apresentam um modelo de simulação de eventos discretos para a análise da descarga de grãos, armazenamento e descarga de materiais em uma refinaria de alumínio na Europa. Em seu modelo são considerados novos recursos, como a inclusão de funcionalidades adicionais de descarregamento, novas unidades auxiliares de infraestrutura e organização eficiente do agendamento de manutenção na cadeia de processamento de materiais. O modelo foi utilizado para prever e avaliar o ganho de desempenho em um sistema portuário em cenários de investimento e planejamento. Foram identificadas orientações promissoras em termos de indicadores de desempenho em larga escala, como a extensão da instalação de descarga em conjunto com uma configuração de manutenção apropriada, investimento que reduziria as horas gastas em filas em $26 \%$ do valor histórico, levando a uma redução de custo de aproximadamente 16\%. Também foram realizadas análises quanto às expansões da capacidade do transportador e o aumento das taxas de descarga. Ao término dessas análises, observou-se que os custos cairiam para menos de $10 \%$ do valor histórico caso as modificações sugeridas fossem implementadas.

Pratap et al. (2018) desenvolveram um modelo de suporte à decisão, que trata da dinâmica do porto e auxilia na melhor tomada de decisão em diferentes cenários em um porto graneleiro. Foram descritas várias decisões tomadas pelas autoridades portuárias relativas à importação no terminal. Essas decisões foram otimizadas com o objetivo de minimizar o tempo de descarga dos navios no porto, congestionamento no pátio de carga e tempo de carregamento dos trens. Esse modelo de suporte também visa aumentar a utilização dos postos de ancoragem, de pátios, de ramais, de estações de carregamento e a eficiência do porto. A utilidade do modelo desenvolvido foi demonstrada por meio de um estudo de caso que constatou uma melhora na eficiência dos berços, na estocagem e no carregamento das cargas. 


\subsection{Conclusão da revisão bibliográfica}

O objetivo principal desta seção foi demonstrar a aplicação prática da simulação, em particular daquelas que foram aplicadas em terminais portuários. Os objetivos propostos foram atingidos através da revisão bibliográfica da(s) simulação/sugestões e das formas de utilização da ferramenta de simulação para a otimização portuária.

A simulação não é utilizada para encontrar a resposta para algum problema do sistema, mas sim para verificar as características comportamentais deste, entender os efeitos de mudanças e as relações entre os componentes. A simulação tem diversas vantagens, e a principal delas é permitir às empresas experimentar mudanças nas regras de decisão sem interrupção das operações do sistema real. Outra vantagem é a capacidade do modelo de simulação computacional para reduzir o tempo do experimento, permitindo aos tomadores de decisão prever as consequências a longo prazo das possíveis ações efetuadas. Além disso, a simulação traz uma visão sistêmica do efeito que alterações pontuais terão sobre o desempenho global do sistema, aumentando a eficiência deste na utilização de recursos.

Diante do crescimento das empresas e da expansão de suas estruturas, conclui-se que a simulação computacional ajuda o planejador a tomar uma decisão, constituindo uma ferramenta muito útil para lidar com os novos desafios do mundo. 


\section{SISTEMA DE RECEBIMENTO DO TERMINAL PORTUÁRIO}

Como dito no primeiro capítulo, este trabalho trata da modelagem de um sistema de recebimento de caminhões e trens em um terminal portuário. Portanto, serão apresentadas as principais características físicas do sistema de estudo que tornarão possível o entendimento do modelo proposto.

O terminal portuário, localizado no Porto de Santos (SP), foi inaugurado em 1998 para fins de exportação. No terminal há uma diversificação na movimentação de cargas, com embarques de açúcar, de soja e de milho. Na Safra 2017-2018, 4,5 milhões de toneladas de açúcar foram movimentados nesse terminal, sendo 2,9 milhões destinadas ao mercado externo.

Dois outros terminais multimodais que integram a malha logística estão localizados em Ribeirão Preto e em São José do Rio Preto, no interior de São Paulo.

\section{Terminal Multimodal de São José do Rio Preto (SP)}

Este terminal multimodal (rodoviário e ferroviário) tem capacidade de movimentação de 700 mil toneladas de açúcar por ano. Por possuir operações de transbordo, a unidade recebe açúcar via transporte rodoviário e remete esse produto via trem, com destino ao terminal portuário de Santos (SP).

\section{Terminal Multimodal de Ribeirão Preto (SP)}

Este terminal multimodal (rodoviário e ferroviário) começou a operar em 2010 e concentra suas atividades nas operações de transbordo. Ele recebe açúcar via transporte rodoviário e embarca esse produto em ferrovia com destino ao terminal portuário de Santos (SP). Esse terminal multimodal tem capacidade de movimentação de 1,5 milhão de toneladas de açúcar por ano. 


\subsection{Transporte de cargas agrícolas no Porto de Santos}

Os modais utilizados para o recebimento de carga nesse terminal portuário de Santos são: os modais rodoviário e ferroviário.

\subsubsection{Modal Rodoviário}

As cargas que chegam ao Porto de Santos pelo sistema rodoviário são transportadas através das principais rotas da região Sudeste até o porto, que são as rodovias: Rodovia Padre Manuel da Nóbrega, Rodovia Piaçaguera-Guarujá, Via Anchieta, Rodovia dos Imigrantes e Rodovia Rio-Santos (CODESP, 2016), como está destacado na figura 5 .

Figura 5 - Principais rodovias para o Porto de Santos

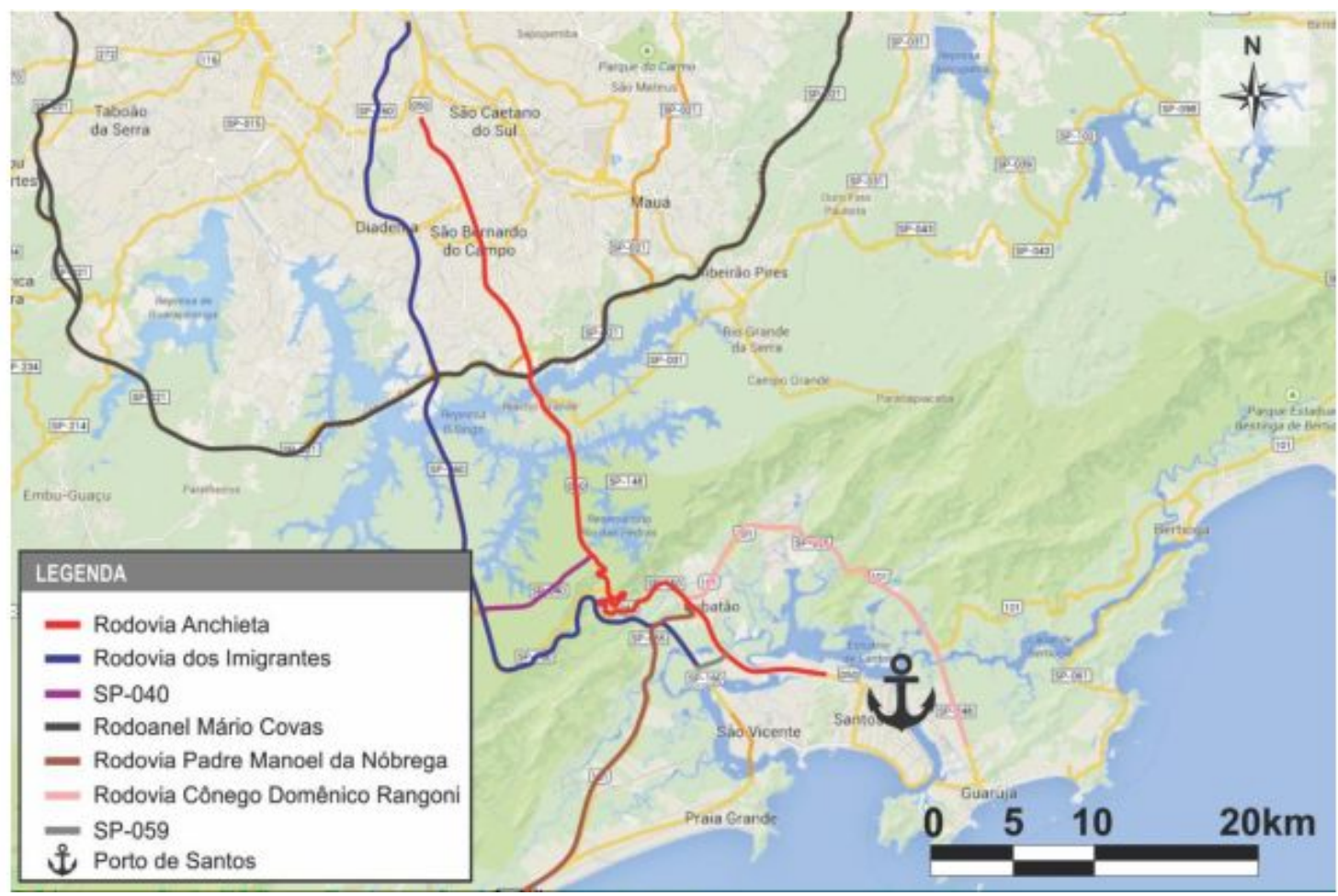

Fonte: Oliveira (2016). 


\subsubsection{Pátios reguladores}

A Codesp ${ }^{2}$ estabelece que os caminhões transportadores de granel sólido para exportação são obrigados a fazer uso dos Pátios Reguladores credenciados, antes de se direcionarem aos terminais de destino (CODESP, 2014).

O propósito dos pátios reguladores é evitar o deslocamento direto da safra agrícola para o Porto de Santos nas cidades da Baixada Santista.

Com o objetivo de evitar congestionamentos nas estradas que atendem os municípios da região, os veículos devem ser direcionados aos pátios reguladores antes de continuarem em direção aos terminais graneleiros. Portanto, o controle dos caminhões é realizado pelos pátios reguladores (Palos e Souza, 2017).

Os pátios reguladores estão localizados em Cubatão (SP) e Sumaré (SP). Os pátios localizados em Cubatão são: o Rodopark Logística e o Ecopátio do grupo EcoRodovias, e em Sumaré se encontra a Rumo Logística do Grupo Cosan (Monteiro, 2015). O sistema avaliado neste estudo utiliza somente o Ecopátio como pátio regulador.

O Ecopátio possui área total de $446.000 \mathrm{~m}^{2}$, com $8.000 \mathrm{~m}^{2}$ de armazéns e $440.000 \mathrm{~m}^{2}$ de pátio, e tem capacidade para receber 1.000 caminhões a granel. Localiza-se a $18 \mathrm{~km}$ do Porto de Santos, com tempo médio de permanência dos caminhões de 6 horas. A figura 6 a seguir mostra o Ecopátio (Melício, 2018).

\footnotetext{
${ }^{2}$ Companhia Docas do Estado de São Paulo.
} 
Figura 6 - Ecopátio do Porto de Santos em Cubatão

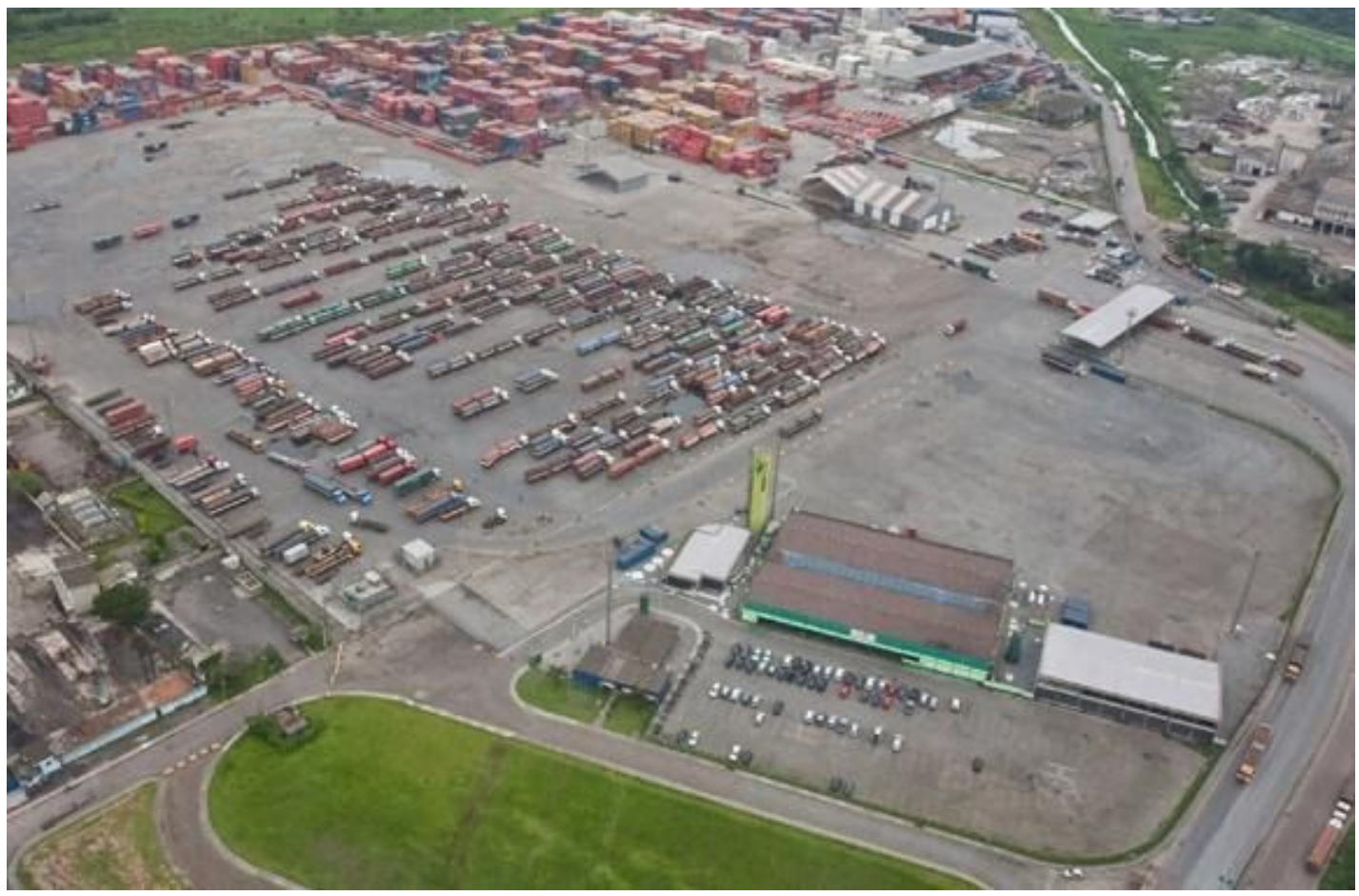

Fonte: Agência Transporta Brasil (2012).

\subsubsection{Terminal portuário}

Segundo a empresa, o terminal tem capacidade para receber em média 600 caminhões e 200 vagões por dia. Antes do descarregamento, alguns veículos têm que passar pela amostragem. A amostragem é feita em todos os caminhões que carregam grãos e apenas com alguns que carregam açúcar. Após a amostragem, o caminhão retorna à fila de descarregamento e lá permanece até ser liberado pela análise.

O terminal portuário conta com 8 moegas separadas em 4 corredores. No primeiro corredor, as moegas 1 e 2 têm capacidade de $900 \mathrm{t} / \mathrm{h}$. No segundo corredor, as moegas 3 e 4 têm capacidade de 1200 t/h. No terceiro corredor, as moegas 5 e 6 têm uma capacidade de $1200 \mathrm{t} / \mathrm{h}$. No quarto corredor, as moegas 7 e 8 têm capacidade de $1800 \mathrm{t} / \mathrm{h}$.

Antes de passar pelas moegas, o caminhão tem que ser pesado e existe uma restrição de balança. As balanças para as moegas 1, 7, 8 não suportam caminhões maiores que 7 eixos. 


\subsection{Dados Específicos}

Algumas especificações referentes ao processo de escoamento de grãos serão apresentadas para melhor entendimento do sistema considerado.

Os diferentes tipos de embalagens utilizadas no processo de transporte do açúcar para exportação influenciam no valor do frete. Os principais tipos são: a saca solta, a big bag e a granel. No terminal portuário analisado, somente o transporte a granel é utilizado, devido a sua eficiência nos momentos de carregamento e descarregamento do produto (Carvalho, 2005).

Outro fator relevante para o transporte do açúcar é o tipo de equipamento utilizado para transportá-lo, ou seja, o modelo de caminhão utilizado para o serviço. São dois os tipos de caminhões mais utilizados no transporte de produtos agrícolas no estado de São Paulo, quais sejam:

- Graneleiro: são caminhões com capacidade média de 28 toneladas e comportam os três tipos de embalagens citados anteriormente. Por não possuírem uma caçamba móvel, necessitam de tombadores para efetuar o serviço de descarga nos portos ou em outros locais. Atualmente, pode-se encontrar graneleiros com capacidade para 40 toneladas (bitrens) e também para 60 toneladas (rodotrens);

- Basculante: são caminhões com as mesmas características dos graneleiros. Porém, possuem um sistema hidráulico para movimentação da caçamba, dispensando o uso de outra tecnologia para descarregamento do produto. Atualmente, novas tecnologias estão sendo testadas com os caminhões basculantes no transporte do açúcar para que sua capacidade seja ampliada para 40 toneladas ou até 60 toneladas.

O tombador é um sistema mecânico utilizado para descarregar o caminhão em armazéns. Basicamente, são superfícies que inclinam o caminhão em 
aproximadamente $40^{\circ}$ a $45^{\circ}$ em relação ao solo, como mostra a 7 a seguir (Silva, 2010).

Figura 7 - Desenho esquemático: tombador empregado para descarga de caminhões

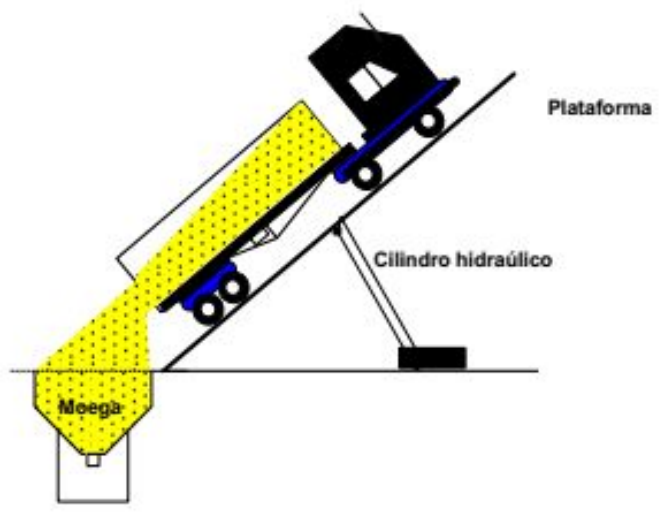

Fonte: Silva (2010).

Dados obtidos em terminais de açúcar localizados no Porto de Santos indicam que um caminhão graneleiro demora mais para descarregar do que um caminhão basculante. Portanto, é evidente que a demanda pelo caminhão basculante é maior, tendo como principal consequência um custo de transporte maior (Carvalho, 2005).

\subsection{Caracterização Do Estudo De Caso}

Essa seção tem por objetivo apresentar o estudo de caso da pesquisa, o qual será modelado. Esse estudo de caso consiste no recebimento de granéis agrícolas no terminal portuário. Os processos simulados compreendem desde a chegada dos grãos até o seu descarregamento.

O foco do estudo de caso é o conjunto dos processos decisórios existentes na operação desse sistema, como gerenciamento de filas, por exemplo. Por meio da modelagem proposta serão avaliadas e determinadas estratégias operacionais que resultem no melhor desempenho possível para o sistema. Portanto, em primeiro lugar é necessário definir como o desempenho do sistema será medido. 


\subsubsection{Avaliação de desempenho do sistema}

Para a avaliação do sistema será considerado o total de grãos escoados pelos caminhões e trens. As outras medidas de desempenho, como tempo médio de espera nas filas dos caminhões, ocupação das moegas, número de caminhões e vagões atendidos também serão consideradas na avaliação do sistema.

\subsubsection{Etapas do transporte de grãos}

Para facilitar a compreensão do sistema a ser modelado, foram analisadas as etapas do transporte rodoviário e ferroviário de grãos para o terminal, com o intuito de desenvolver um modelo que represente o sistema real.

\section{Trajeto dos caminhões com grãos para o terminal portuário}

Os produtos transportados pelos caminhões passam por várias etapas antes de serem escoados. As etapas são:

- Chegada dos caminhões ao Ecopátio;

- Saída dos caminhões do Ecopátio para o terminal;

- Chegada dos caminhões ao terminal portuário;

- Cadastramento dos caminhões no sistema;

- Verificação da passagem do caminhão pela amostragem³;

- Direcionamento dos caminhões para a triagem;

- Descarregamento dos caminhões em moegas;

- Saída do caminhão do sistema.

\footnotetext{
${ }^{3} \mathrm{~A}$ amostragem é o processo que seleciona um grupo de indivíduos de uma população, com a finalidade de estudar e caracterizar a população total. Nesse caso, verifica-se a qualidade do produto transportado.

${ }^{4}$ Moegas são estruturas usadas para a recepção de produtos a granel.
} 
Os caminhões permanecem em um Ecopátio aguardando o chamado para o porto. Ao chegarem ao porto, eles formam uma fila única e são cadastrados no sistema. Após o cadastramento, são encaminhados para amostragem. A amostragem é realizada em todos os caminhões que carregam grãos, mas somente em alguns que carregam açúcar. Em seguida, esses caminhões são separados em 4 filas, sendo uma de grãos e três de açúcar, onde é realizada a triagem. Os caminhões são pesados antes e depois do descarregamento nas moegas, após a triagem. A figura 8 mostra o modelo conceitual de descarga dos caminhões: 
Figura 8 - Modelo Conceitual de Descarga dos Caminhões

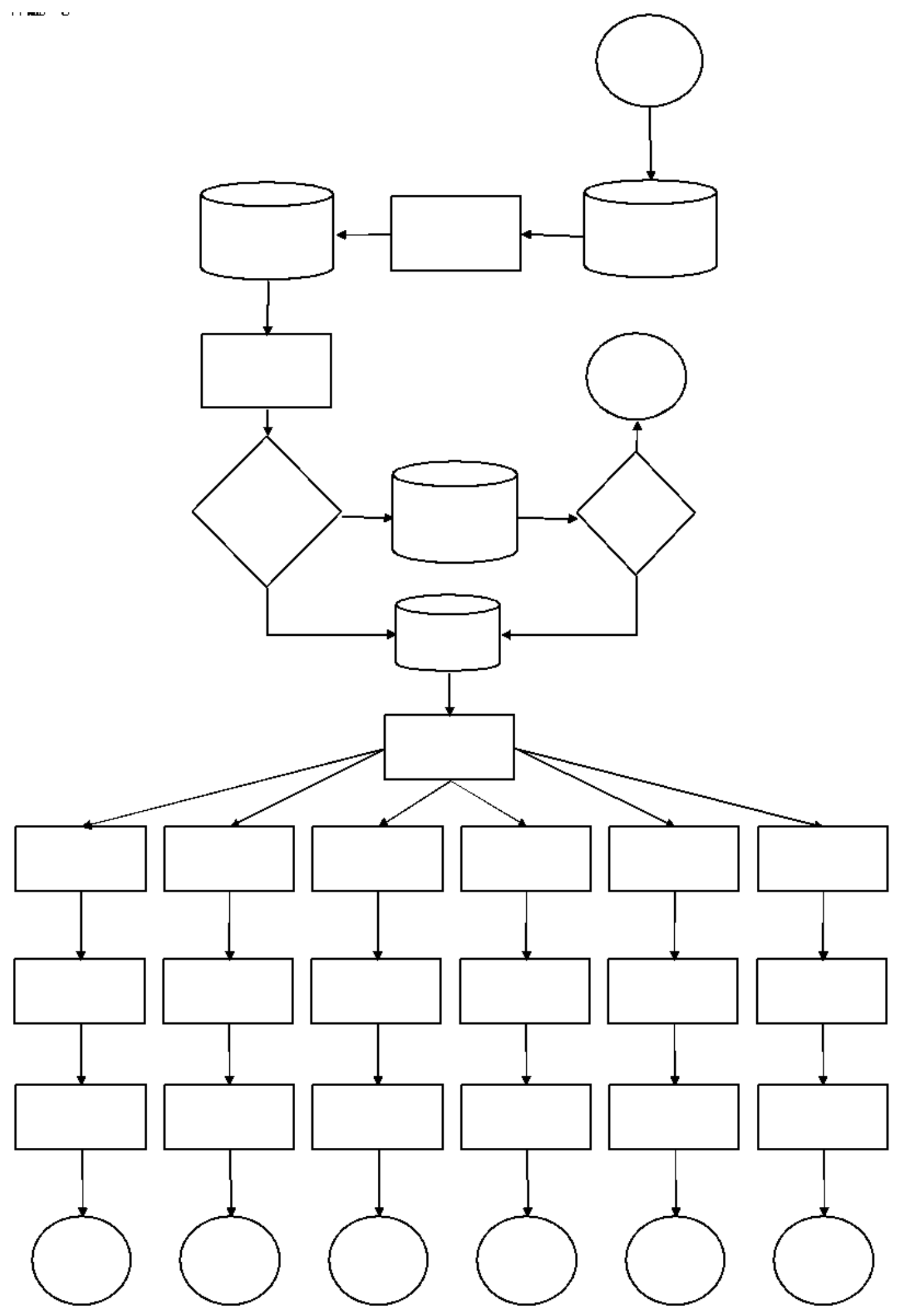

Fonte: Autor (2020). 
Trajeto dos trens com grãos para o terminal portuário

Os produtos transportados pelos trens passam por várias etapas antes de serem escoados. As etapas são:

- Chegada dos trens ao terminal portuário;

- Cadastramento dos trens no sistema;

- Direcionamento dos trens para a triagem;

- Descarregamento dos vagões em moegas;

- Saída do trem do sistema.

Os trens têm uma previsão de chegada, e ao entrarem no porto são atendidos no mesmo momento. Em seguida, são cadastrados e encaminhados para a triagem. Após a triagem, eles são pesados antes e depois do descarregamento nas moegas. A figura 9 mostra o modelo conceitual de descarga dos trens.

Figura 9 - Modelo Conceitual de Descarga dos Trens

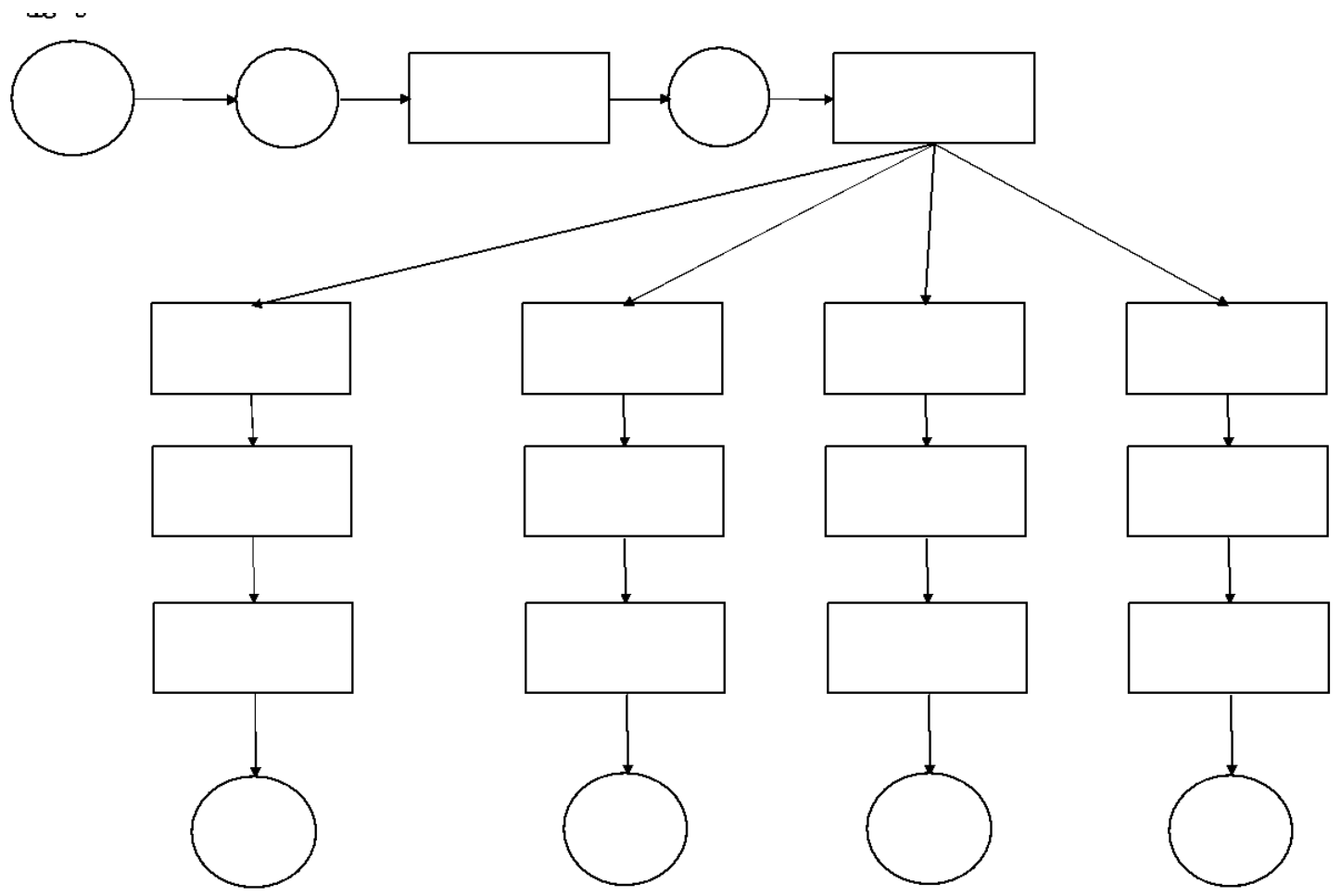

Fonte: Autor (2020). 


\section{MODELO PROPOSTO}

\subsection{Dados necessários para a pesquisa}

Para a construção do modelo realizou-se um estudo dos dados do terminal portuário a fim de determinar o comportamento de cada uma das variáveis de entrada do modelo. Os dados para a pesquisa envolvem toda a cadeia produtiva do terminal portuário.

Dados de entrada do modelo:

- Descrição dos veículos;

- Tempo de pesagem dos caminhões;

- Tempo de pesagem dos vagões;

- Tempo de descarregamento dos caminhões;

- Tempo de descarregamento dos vagões;

- Taxa de chegada dos caminhões;

- Taxa de chegada dos vagões;

- Capacidade de carga dos caminhões;

- Capacidade de carga dos vagões;

- Capacidade de descarga de caminhões nos terminais.

Devido às exigências de confidencialidade e segurança de dados, diversas informações solicitadas foram fornecidas pelo terminal portuário em formato distinto do solicitado ou não foram fornecidas. Por essa razão, análises dos dados fornecidos pelo terminal não foram realizadas.

Análise geral das principais variáveis de saída do modelo:

- Total de grãos escoados pelos caminhões e trens;

- Tempo médio dos caminhões nas filas; 
- Ocupação das moegas;

- Número de caminhões atendidos;

- Número de vagões atendidos.

\subsection{Descrição do modelo de simulação}

O modelo de simulação foi elaborado com base no modelo conceitual descrito anteriormente. Foi utilizado o software Simul8 para criar esse modelo. Para a análise da capacidade máxima de grãos que o terminal pode escoar durante o período de um ano, foram criados 4 cenários com 5 ordens de despacho diferentes. Primeiro será descrito de forma geral como esses cenários funcionam. Logo após essa descrição serão apresentadas as 5 ordens de despacho e finalmente as diferenças entre cada um desses cenários.

\subsubsection{Descrição geral do modelo}

O modelo foi programado para simular um cenário de um ano e seu aquecimento foi de 1 dia, pois é tempo suficiente para que os caminhões se organizem no sistema. Todas as etapas descritas foram validadas pela pessoa que gerencia os processos no Terminal Portuário.

\section{- Chegada de caminhões}

O modelo de simulação se limita a criar caminhões, e tem como finalidade determinar a capacidade máxima de escoamento de grão do terminal portuário. $O$ sistema é composto de 150 caminhões, e sempre que um caminhão sai do sistema ou entra na balança (para ser descarregado) um novo caminhão é criado no processo, assim possibilitando a determinação da quantidade de grãos que o terminal pode oferecer durante $o$ ano. 
- Chegada dos trens

Quando o trem chega ao terminal portuário ele é imediatamente atendido, e o terminal não pode determinar quando o trem irá chegar. Por esse motivo, não houve variação no volume de carga transportado nos trens entre os cenários. Segundo informações do terminal portuário, os trens com açúcar chegam aproximadamente, segundo distribuição exponencial, em média em 2160 minutos; já os trens com grãos chegam aproximadamente, segundo distribuição exponencial, em média em 2880 minutos. Cada trem tem 80 vagões e o tempo de descarregamento de um vagão varia de 23 a 25 minutos.

\section{- Agendamento do Caminhão}

Como os caminhões são apenas colocados no sistema sem qualquer parâmetro, o agendamento fornece esses parâmetros, tais como quantidade de carga, tipo de produto e tamanho do caminhão (7 ou 9 eixos). Esses parâmetros são importantes para o sistema mensurar a quantidade transportada e verificar as restrições de tamanho e produto. Com o agendamento a ordem de despacho do caminhão é definida.

\section{- Entrada e saída do pátio regulador}

Com base no trabalho de Melício (2018) - Pátio Regulador na Ótica do Usuário - depois do agendamento o caminhão vai para o pátio (Ecopátio). Nesse trabalho foi mostrado que na entrada do pátio existem 6 portões e o tempo médio de liberação do veículo é de 45 segundos; já a saída possui 3 portões e o tempo médio de liberação é de 25 segundos. O terminal portuário informou que tem um contrato com o Ecopátio de 280 vagas, que podem ser revezadas ao longo do dia. 


\section{- Entrada do terminal}

Do pátio (Ecopátio) até o terminal portuário estima-se um tempo de 30 a 45 minutos. Na chegada ao terminal portuário o caminhão é direcionado para a fila de recepção, essa fila tem no máximo 10 caminhões devido da restrição de espaço. $A$ recepção envia todos os caminhões com grãos para a amostragem e seleciona quais caminhões com açúcar irão para a amostragem.

\section{- Separação das filas para o descarregamento}

Os caminhões são separados pela triagem em quatro filas: duas filas para açúcar e duas filas para soja, cada uma das filas com capacidade máxima de 10 caminhões, devido a restrição de espaço. Essas filas são referentes à emissão de documentos e liberação de caminhões para descarregar, e o tempo estimado desse procedimento, segundo o terminal portuário, é de 9 a 13 minutos.

\section{- Descarregamento dos caminhões}

A primeira fila (açúcar) é dividida em duas filas, uma para a balança 1 e outra para a balança 2. A balança 1 não tem capacidade de pesar um caminhão de 9 eixos, ao contrário da balança 2. Logo após a pesagem o caminhão da balança 1 é direcionado à moega 1 e o caminhão da balança 2 é direcionado à moega 2 , e assim são descarregados. O caminhão demora cerca de 10 a 18 minutos para descarregar o açúcar ou os grãos em uma moega. Depois da descarga, o caminhão é pesado por uma única balança e em seguida ele sai do sistema.

A segunda fila (açúcar) não tem restrição de tamanho e também é dividida em duas, uma para a balança 3 e outra para a balança 4. Logo após a pesagem, o caminhão da balança 3 é direcionado à moega 3 e o caminhão da balança 4 é direcionado à moega 4, e assim são descarregados. Depois da descarga, o caminhão é pesado por uma única balança e então ele sai do sistema. Essa segunda fila sofre interferência da ferrovia, pois os vagões de açúcar também descarregam na moega 4 e na moega 5, seguindo a mesma ordem dos caminhões: pesagem, descarregamento e pesagem novamente. 
A terceira fila (grão) tem somente uma balança, que serve tanto para a moega 5 quanto para a moega 6 , e nessa balança não há restrição de tamanho para os caminhões. Logo após a pesagem o caminhão é direcionado à moega 5 ou à moega 6 , e assim é descarregado. Depois da descarga o caminhão é pesado por uma única balança e então ele sai do sistema.

A quarta fila (grão) tem somente uma balança, que serve tanto para a moega 7 quanto para a moega 8 . Na quarta fila há restrição de tamanho para os caminhões. Logo após a pesagem, o caminhão é direcionado à moega 7 ou à moega 8 , e assim é descarregado. As moegas 7 e 8 possuem uma peculiaridade: uma está localizada em frente à outra. Portanto, para entrar na moega 8 é necessário que a moega 7 esteja vazia, e para sair da moega 7 é preciso que a moega 8 esteja vazia. Essa fila sofre interferência da ferrovia, pois os vagões de grãos também descarregam na moega $7 \mathrm{e}$ na moega 8 , seguindo a mesma ordem dos caminhões: pesagem, descarregamento e pesagem novamente.

\subsection{Diagrama no terminal portuário}

A figura 10 apresenta o diagrama dos caminhões no terminal portuário, da entrada no terminal até as filas. A figura 11 mostra o diagrama dos caminhões e trens no terminal portuário, das filas até a saída do terminal. 
Figura 10 - Representação do sistema de filas de descarregamento (da entrada até as filas)

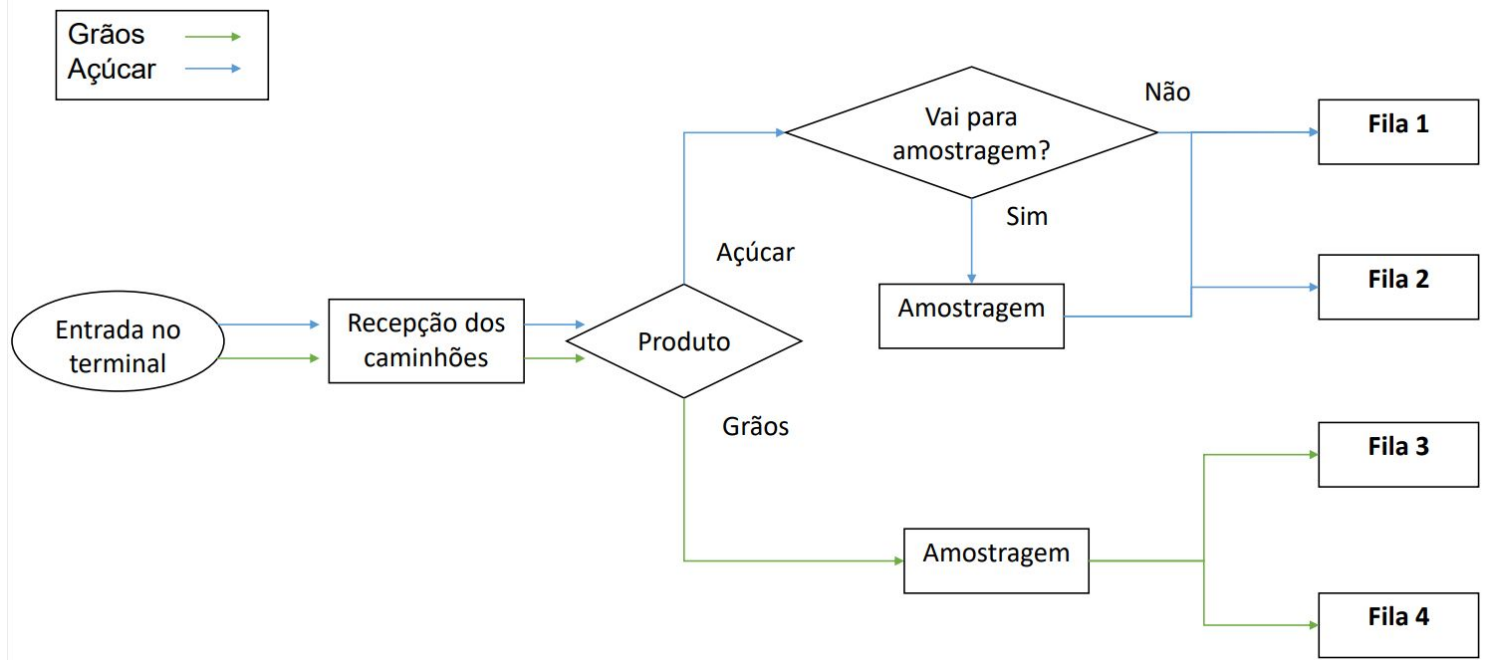

Fonte: Autor (2020).

Figura 11 - Representação do sistema de filas de descarregamento (das filas até a saída do terminal)

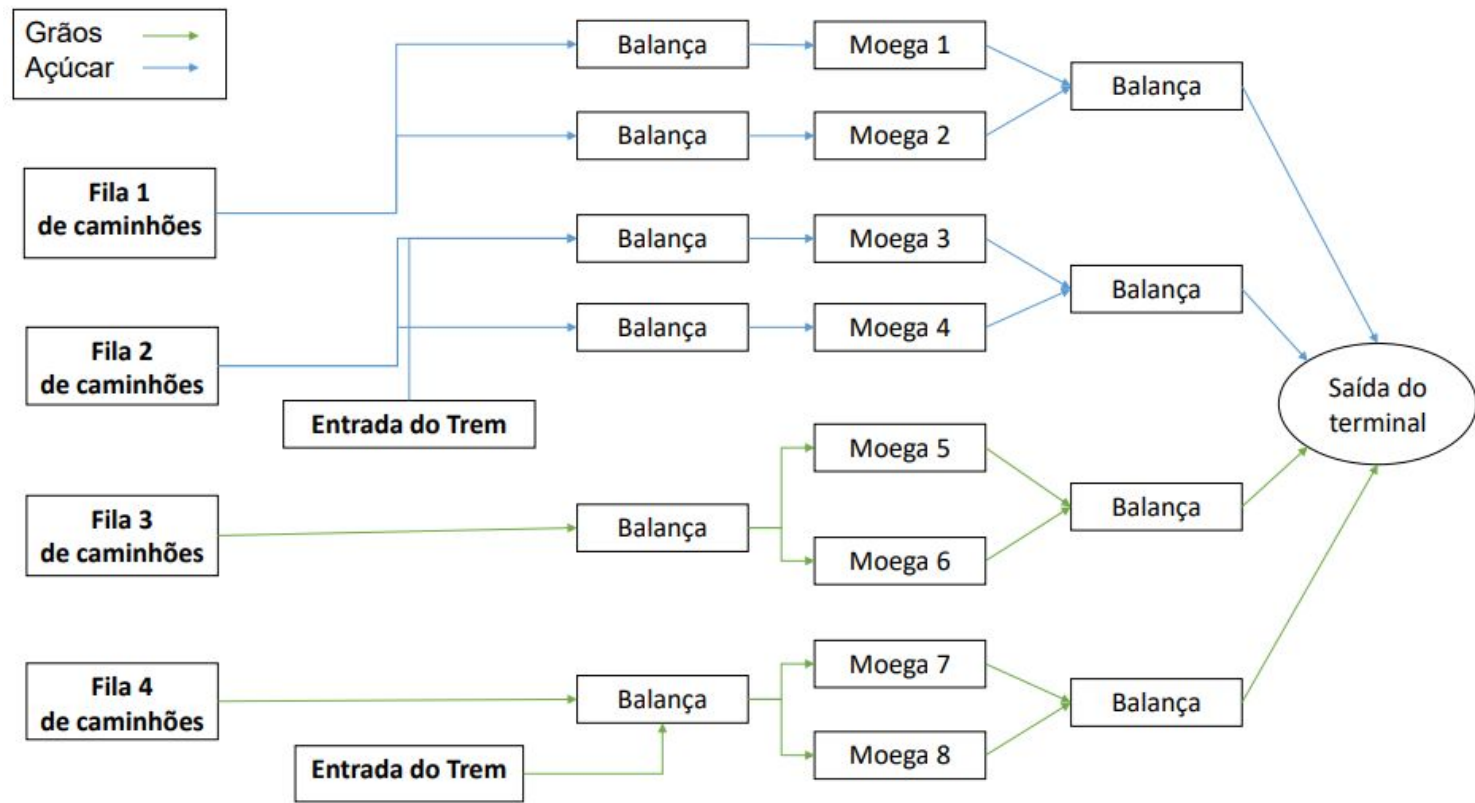

Fonte: Autor (2020). 


\subsection{Ordens de despacho dos caminhões}

A primeira ordem de despacho é uma situação em que só existem caminhões de 7 eixos. No agendamento segue um caminhão de 7 eixos com açúcar e outro com grãos, respectivamente.

A segunda ordem de despacho é uma situação em que só existem caminhões de 9 eixos. No agendamento segue um caminhão de 9 eixos com açúcar e outro com grãos, respectivamente.

A terceira ordem de despacho é uma situação em que o agendamento dos caminhões acontece de forma aleatória. Portanto, não há uma ordem a ser seguida, havendo 4 possibilidades de caminhões: de 7 eixos com açúcar, de 7 eixos com grãos, de 9 eixos com açúcar e de 9 eixos com grãos.

A quarta ordem de despacho é uma situação em que o agendamento dos caminhões acontece respeitando-se a ordem das filas, alternando entre grão e açúcar, priorizando os caminhões de 7 eixos. Logo, a ordem é caminhão de 7 eixos com açúcar, caminhão de 7 eixos com grãos, caminhão de 9 eixos com açúcar e caminhão de 9 eixos com grãos. A ordem das filas é fila 1, fila 4, fila 2 e fila 3.

A quinta ordem de despacho é uma situação em que o agendamento dos caminhões ocorre de acordo com a ordem das moegas, alternando entre grão e açúcar. Logo, a ordem é caminhão de 7 eixos com açúcar, caminhão de 9 eixos com grãos, caminhão de 9 eixos com açúcar, caminhão de 9 eixos com grãos, caminhão de 9 eixos com açúcar, caminhão de 7 eixos com grãos, caminhão de 9 eixos com açúcar e caminhão de 7 eixos com grãos. A ordem das moegas é moega 1, moega 5 , moega 2 , moega 6 , moega 3 , moega 7 , moega 4 e moega 8.

\subsection{Diferenças entre os cenários}

O primeiro cenário é o mais simples, seguindo as restrições de tamanho e produto como todos os cenários. Portanto, esse cenário não indica a melhor fila para o caminhão entrar e não muda o trajeto do caminhão, de modo que, quando um trem chega, o caminhão tem que esperar na fila até o trem estar totalmente descarregado, e só depois ocorre o descarregamento do caminhão. 
O segundo cenário considera possíveis mudanças de rota do caminhão. Assim, o caminhão é direcionado de acordo com o tempo gasto na fila, mas ele não é direcionado para a menor fila, sempre sendo respeitadas as restrições de tamanho e produto.

O terceiro cenário considera possíveis mudanças de rota do caminhão, com este devendo ser encaminhado para a menor fila, sempre sendo respeitadas as restrições de tamanho e produto.

O quarto cenário considera possíveis mudanças de rota do caminhão, com este sendo direcionado para a menor fila e havendo um "organizador" que pode mudar a sequência dos caminhões que saem do pátio. O "organizador" considera que há 4 cenários possíveis, que são: sem nenhum trem, somente com o trem com açúcar, somente com o trem com grãos e com ambos os trens. O "organizador" tem a função de ordenar os caminhões com o objetivo de aumentar o escoamento dos produtos. 


\section{ANÁLISE DE CENÁRIOS}

Nesse capítulo foi analisado cada um dos cenários, e essa análise também considerou as cinco formas de despacho para cada cenário. Cabe lembrar que o "organizador" está no cenário 4, e ele serve de suporte à decisão com o propósito de ajudar os planejadores portuários a ordenar os caminhões.

\subsection{Análise do cenário 1}

O primeiro cenário foi o que apresentou a menor carga total entre todos os demais cenários. Nele os caminhões permanecem na fila após serem direcionados e algumas filas não são liberadas até o atendimento completo do trem. Os números relativos à quantidade de carga transportada são exibidos na tabela 1.

Tabela 1 - Quantidade de carga transportada no cenário 1

\begin{tabular}{llrrrrr}
\hline Objeto de Simulação & Medida de performance & $\mathbf{1 . 1}$ & $\mathbf{1 . 2}$ & $\mathbf{1 . 3}$ & \multicolumn{1}{c}{1.4} & \multicolumn{1}{c}{1.5} \\
\hline Carga Total $(t)$ & Valor & 5.958 .908 & 7.213 .196 & 7.047 .530 & 7.105 .093 & 7.276 .547 \\
\hline Açúcar $(t)$ & Valor & 3.210 .701 & 3.843 .608 & 3.740 .972 & 3.788 .448 & 3.963 .013 \\
Soja $(t)$ & Valor & 2.748 .207 & 3.369 .588 & 3.306 .558 & 3.316 .645 & 3.313 .534 \\
\hline Quantidade de caminhões & Valor & 82.856 & 83.072 & 93.590 & 94.401 & 94.229 \\
Carga de caminhões & Valor & 3.148 .528 & 4.402 .816 & 4.237 .150 & 4.294 .713 & 4.466 .167 \\
Quantidade de vagões & Valor & 33.860 & 33.860 & 33.860 & 33.860 & 33.860 \\
Carga de trens & Valor & 2.810 .380 & 2.810 .380 & 2.810 .380 & 2.810 .380 & 2.810 .380 \\
\hline
\end{tabular}

Fonte: Autor (2020).

A tabela apresenta os resultados do cenário 1 em todas as formas de despacho, portanto a situação 1.1 significa cenário 1 na forma de despacho $1 \mathrm{e}$ situação 1.2 significa cenário 1 na forma de despacho 2 e assim sucessivamente.

A melhor forma de despacho foi a 5 , baseada na ordem das moegas. A quantidade de açúcar é maior do que a quantidade de grãos, e isso se deve ao fato de os trens com açúcar chegarem com mais frequência do que os trens com grãos e à maior capacidade de atendimento por parte das moegas de açúcar.

A maior quantidade de caminhões foi constatada na forma de despacho 1.4. Apesar de a forma de despacho 1.1 ser a menos restrita (com somente caminhões de 7 eixos), ela apresentou a menor quantidade de caminhões devido às limitações do cenário 1 . O despacho 1.2 foi o segundo melhor, mesmo sendo o de maior restrição, 
porque todos os caminhões eram de 9 eixos, e isso se deve também às limitações do cenário. A carga do trem não muda, pois o terminal não tem controle sobre o trem, logo somente pode ser verificada a interferência do trem no descarregamento dos caminhões. O número de descargas realizadas pelas moegas é exposto na tabela 2.

Tabela 2 - Número de descargas por moegas realizadas no cenário 1

\begin{tabular}{|c|c|c|c|c|c|c|}
\hline Objeto de Simulação & Medida de performance & 1.1 & 1.2 & 1.3 & 1.4 & 1.5 \\
\hline Moega 1 & Número de trabal hos concluídos & 10.449 & 0 & 6.115 & 5.953 & 2.941 \\
\hline Moega 2 & Número de trabal hos concluídos & 10.435 & 20.948 & 17.310 & 17.840 & 20.810 \\
\hline Moega 3 & Número de trabal hos concluídos & 20.231 & 20.266 & 21.499 & 21.688 & 21.660 \\
\hline Moega 4 & Número de trabal hos concluídos & 20.234 & 20.250 & 21.507 & 21.687 & 21.672 \\
\hline Moega 5 & Número de trabal hos concluídos & 10.269 & 20.582 & 15.482 & 14.639 & 15.910 \\
\hline Moega 6 & Número de trabal hos concluídos & 10.269 & 20.582 & 15.481 & 14.640 & 15.910 \\
\hline Moega 7 & Número de trabal hos concluídos & 9.319 & 7.143 & 8.141 & 8.430 & 7.961 \\
\hline Moega 8 & Número de trabal hos concluídos & 25.526 & 7.177 & 21.931 & 23.400 & 21.241 \\
\hline Final & Número de trabal hos concluídos & 116.731 & 116.949 & 127.465 & 128.277 & 128.106 \\
\hline
\end{tabular}

Fonte: Autor (2020).

As moegas mais utilizadas foram aquelas com as quais os trens têm ligação, moegas 3, 4 e 8, em virtude de este cenário não direcionar o caminhão para a melhor fila. A moega 7 foi a que recebeu menor quantidade de produtos descarregados, pois ela está em paralelo com a moega 8 , que por sua vez foi priorizada. A situação 1.1 foi aquela em que se aproveitou mais a moega 1 por causa da restrição de tamanho. $\mathrm{Na}$ situação 1.2 a moega 1 não pôde ser utilizada devido ao tamanho e as moegas 7 e 8 foram utilizadas somente pelos trens. O tempo das filas no sistema é apresentado na tabela 3.

Tabela 3 - Tempo médios das filas dos caminhões no cenário 1

\begin{tabular}{|c|c|c|c|c|c|c|}
\hline Objeto de Simulação & Medida de performance & 1.1 & 1.2 & 1.3 & 1.4 & 1.5 \\
\hline Tempo médio no sistema ( $\mathrm{min}$ ) & Tempo médio no sistema & 918 & 911 & 842 & 836 & 837 \\
\hline Tempo médio da Fila 1 (min) & Tempo médio no sistema & 53 & 11 & 98 & 113 & 99 \\
\hline Tempo médio da Fila 2 (min) & Tempo médio no sistema & 131 & 143 & 129 & 124 & 127 \\
\hline Tempo médio da Fila 3 (min) & Tempo médio no sistema & 1 & 103 & 80 & 55 & 90 \\
\hline Tempo médio da Fila 4 (min) & Tempo médio no sistema & 218 & 0 & 130 & 141 & 132 \\
\hline \multirow[t]{2}{*}{ Fila do pátio } & Tempo médio no sistema & 570 & 580 & 489 & 485 & 482 \\
\hline & Tamanho médio da fila & 91 & 93 & 88 & 88 & 87 \\
\hline Fila da Recepção & Tempo médio no sistema & 62 & 63 & 54 & 54 & 54 \\
\hline
\end{tabular}

Fonte: Autor (2020).

Destaca-se que esse modelo foi feito somente para testar a oferta de grão que o terminal pode escoar no período de um ano, logo a quantidade de caminhões será 
sempre mantida no máximo permitido pelo sistema. O tempo médio no sistema é considerado o tempo do caminhão desde a entrada no Ecopátio até a saída pelo terminal portuário. Os tempos no sistema variam entre 836 minutos, na situação 1.4, e 918 minutos, na situação 1.1 .

A situação 1.1 o tempo médio da fila 3 é de 1 minuto, visto que nesse cenário os caminhões não são direcionados para a menor fila e não podem mudar de rota gerando esse resultado. A situação 1.2 o tempo médio da fila 4 é nulo, em razão da forma de despacho de somente de caminhões de 9 eixo e a fila 4 somente ter conexão com moegas que atendem caminhões de 7 eixos.

As filas com maior tamanho são aquelas que têm conexão com o modal ferroviário. Constata-se, na situação 1.3, que as filas 2 e 4 têm duração de 129 minutos e 130 minutos respectivamente, e as filas 1 e 3 têm duração de 98 minutos e 80 minutos respectivamente. O maior tempo de espera fica concentrado no pátio, o que ocorre por não haver espaço suficiente no terminal para estacionar os caminhões. A porcentagem de trabalho, espera e bloqueio no sistema é mostrada na tabela 4.

Tabela 4 - Porcentagem de trabalho, espera e bloqueio no cenário 1

\begin{tabular}{|c|c|c|c|c|c|c|}
\hline Objeto de Simulação & Medida de performance & 1.1 & 1.2 & 1.3 & 1.4 & 1.5 \\
\hline \multirow[t]{2}{*}{ Moega 1} & Esperando \% & 72 & 100 & 83 & 84 & 92 \\
\hline & Trabalhando \% & 28 & 0 & 17 & 16 & 8 \\
\hline \multirow[t]{2}{*}{ Moega 2} & Esperando \% & 77 & 53 & 62 & 60 & 54 \\
\hline & Trabalhando \% & 23 & 47 & 38 & 40 & 46 \\
\hline \multirow[t]{2}{*}{ Moega 3} & Esperando \% & 35 & 35 & 32 & 31 & 31 \\
\hline & Trabalhando \% & 65 & 65 & 68 & 69 & 69 \\
\hline \multirow[t]{2}{*}{ Moega 4} & Esperando \% & 35 & 35 & 32 & 31 & 31 \\
\hline & Trabalhando \% & 65 & 65 & 68 & 69 & 69 \\
\hline \multirow[t]{2}{*}{ Moega 5} & Esperando \% & 76 & 52 & 64 & 66 & 63 \\
\hline & Trabalhando \% & 24 & 48 & 36 & 34 & 37 \\
\hline \multirow[t]{2}{*}{ Moega 6} & Esperando \% & 82 & 65 & 73 & 75 & 73 \\
\hline & Trabalhando \% & 18 & 35 & 27 & 25 & 27 \\
\hline \multirow[t]{2}{*}{ Moega 7} & Esperando \% & 63 & 69 & 66 & 66 & 67 \\
\hline & Trabalhando \% & 37 & 31 & 34 & 34 & 33 \\
\hline \multirow[t]{2}{*}{ Moega 8} & Esperando \% & 19 & 69 & 29 & 25 & 31 \\
\hline & Trabalhando \% & 81 & 31 & 71 & 75 & 69 \\
\hline \multirow[t]{2}{*}{ 1a Liberação do veículo } & Esperando \% & 52 & 52 & 47 & 46 & 46 \\
\hline & Trabalhando \% & 48 & 48 & 53 & 54 & 54 \\
\hline \multirow[t]{2}{*}{ 2a Liberação do veículo } & Esperando \% & 64 & 64 & 60 & 59 & 59 \\
\hline & Trabalhando \% & 36 & 36 & 40 & 41 & 41 \\
\hline \multirow[t]{2}{*}{ 3a Liberação do veículo } & Esperando \% & 65 & 30 & 47 & 50 & 46 \\
\hline & Trabalhando \% & 35 & 70 & 53 & 50 & 54 \\
\hline \multirow[t]{2}{*}{ 4a Liberação do veículo } & Esperando \% & 49 & 100 & 61 & 57 & 63 \\
\hline & Trabalhando \% & 51 & 0 & 39 & 43 & 37 \\
\hline \multirow[t]{2}{*}{ Triagem A } & Esperando \% & 55 & 58 & 40 & 28 & 43 \\
\hline & Bloqueado \% & 45 & 42 & 60 & 72 & 57 \\
\hline \multirow[t]{2}{*}{ Triagem G } & Esperando \% & 34 & 36 & 51 & 64 & 44 \\
\hline & Bloqueado \% & 66 & 64 & 49 & 36 & 56 \\
\hline
\end{tabular}

Fonte: Autor (2020). 
Em razão de limitações deste cenário, a moega 1 fica muito tempo ociosa (72\% a $100 \%$ ). Além disso, devido à forma de despacho adotada na situação 1.2 (todos os caminhões são de 9 eixos), nenhuma tarefa é realizada na moega 1 e não entra nenhum caminhão na $4^{\mathrm{a}}$ liberação do veículo.

Em suma, o cenário 1 apresentou os piores resultados devido as suas restrições, facilitando a análise dos efeitos da mudança de despacho e servindo de ponto de partida para a análise dos outros cenários.

\subsection{Análise do cenário 2}

O segundo cenário mostrou uma melhora dos resultados de $20 \%$ a $36 \%$ no total de carga transportada se comparado ao primeiro cenário. Esse cenário é mais realista do que o primeiro, uma vez que os caminhões podem mudar de trajeto. Logo, quando um trem chega, os caminhões são direcionados para outra fila, sempre sendo respeitadas as restrições de tamanho e produto. Os resultados relativos à quantidade de carga transportada são expostos na tabela 5 .

Tabela 5 - Quantidade de carga transportada no cenário 2

\begin{tabular}{llrrrrr}
\hline Objeto de Simulação & Medida de performance & $\mathbf{2 . 1}$ & $\mathbf{2 . 2}$ & $\mathbf{2 . 3}$ & $\mathbf{2 . 4}$ & $\mathbf{2 . 5}$ \\
\hline Carga Total $(t)$ & Valor & 8.126 .504 & 8.634 .921 & 9.047 .640 & 9.161 .691 & 9.279 .285 \\
\hline Açúcar $(t)$ & Valor & 4.303 .574 & 4.560 .811 & 4.741 .208 & 4.825 .521 & 5.011 .872 \\
Soja $(t)$ & Valor & 3.822 .930 & 4.074 .110 & 4.306 .432 & 4.336 .170 & 4.267 .413 \\
\hline Quantidade de caminhões & Valor & 139.898 & 109.897 & 137.755 & 139.597 & 136.480 \\
Carga de caminhões & Valor & 5.316 .124 & 5.824 .541 & 6.237 .260 & 6.351 .311 & 6.468 .905 \\
Quantidade de vagões & Valor & 33.860 & 33.860 & 33.860 & 33.860 & 33.860 \\
Carga de trens & Valor & 2.810 .380 & 2.810 .380 & 2.810 .380 & 2.810 .380 & 2.810 .380 \\
\hline
\end{tabular}

Fonte: Autor (2020).

A melhor forma de despacho foi a da situação 2.5 , em que se respeitou as ordens das filas como no primeiro cenário. A quantidade transportada de açúcar foi maior do que a quantidade de grãos, por causa da frequência de chegada dos trens. $A$ quantidade de caminhões foi maior na situação 2.1 e menor na 2.2, devido à restrição destes. A carga transportada e a quantidade de vagões não mudam. O número de descargas realizadas nas moegas é apresentado na tabela 6. 
Tabela 6 - Número de descargas realizadas no cenário 2

\begin{tabular}{|c|c|c|c|c|c|c|}
\hline Objeto de Simulação & Medida de performance & 2.1 & 2.2 & 2.3 & 2.4 & 2.5 \\
\hline Moega 1 & Número de trabalhos concluídos & 21813 & 0 & 11402 & 11007 & 6892 \\
\hline Moega 2 & Número de trabalhos concluídos & 21662 & 35049 & 31403 & 32414 & 35854 \\
\hline Moega 3 & Número de trabalhos concluídos & 23317 & 19974 & 22874 & 23275 & 22814 \\
\hline Moega 4 & Número de trabalhos concluídos & 23319 & 19970 & 22873 & 23263 & 22822 \\
\hline Moega 5 & Número de trabalhos concluídos & 24583 & 27230 & 25735 & 25182 & 25964 \\
\hline Moega 6 & Número de trabalhos concluídos & 24584 & 27230 & 25736 & 25182 & 25964 \\
\hline Moega 7 & Número de trabalhos concluídos & 8217 & 7143 & 7813 & 7996 & 7533 \\
\hline Moega 8 & Número de trabalhos concluídos & 26279 & 7177 & 23795 & 25154 & 22513 \\
\hline Final & Número de trabalhos concluídos & 173775 & 143773 & 171630 & 173473 & 170355 \\
\hline
\end{tabular}

Fonte: Autor (2020).

Diferentemente do primeiro cenário, em que as moegas que têm conexão com os trens foram muito mais utilizadas, esse cenário mostra um maior equilíbrio entre as moegas com relação ao número de descargas. Isso ocorre em virtude da possibilidade de o caminhão mudar de trajeto.

A moega 7 continua apresentando o menor número de descargas, por estar paralela à moega 8 . Na situação 2.1, a moega 1 continua sendo a mais aproveitada por causa da restrição de tamanho. Na situação 2.2 a moega 1 não pôde ser utilizada devido ao tamanho dos caminhões e as moegas 7 e 8 somente foram utilizadas pelos trens. O tempo das filas no sistema é mostrado na tabela 7.

Tabela 7 - Tempo médios das filas dos caminhões no cenário 2

\begin{tabular}{|c|c|c|c|c|c|c|}
\hline Objeto de Simulação & Medida de performance & 2.1 & 2.2 & 2.3 & 2.4 & 2.5 \\
\hline Tempo médio no sistema ( $\mathrm{min}$ ) & Tempo médio no sistema & 630 & 760 & 637 & 632 & 646 \\
\hline Tempo médio da Fila 1 (min) & Tempo médio no sistema & 168 & 137 & 154 & 166 & 150 \\
\hline Tempo médio da Fila 2 (min) & Tempo médio no sistema & 79 & 87 & 82 & 79 & 80 \\
\hline Tempo médio da Fila 3 (min) & Tempo médio no sistema & 60 & 90 & 79 & 58 & 68 \\
\hline Tempo médio da Fila 4 (min) & Tempo médio no sistema & 59 & 0 & 36 & 46 & 30 \\
\hline \multirow[t]{2}{*}{ Fila do pátio } & Tempo médio no sistema & 303 & 401 & 308 & 307 & 319 \\
\hline & Tamanho médio da fila & 81 & 85 & 82 & 82 & 84 \\
\hline Fila da Recepção & Tempo médio no sistema & 37 & 47 & 37 & 37 & 38 \\
\hline
\end{tabular}

Fonte: Autor (2020).

Em comparação com o cenário 1 , o tempo de fila diminuiu de $20 \%$ a $46 \%$. Os tempos no sistema variaram entre 630 minutos, na forma de despacho 2.1, e 760 minutos, na forma de despacho 2.2 . 
Em todas as situações a fila 1 é maior. Isso ocorre porque os caminhões podem mudar de trajeto, mas não são direcionados para a menor fila. Portanto, quando um trem chega à fila 1 , ocorre um acúmulo de caminhões com açúcar. $A$ porcentagem de trabalho, espera e bloqueio no sistema é exibida na tabela 8.

Tabela 8 - Porcentagem de trabalho, espera e bloqueio no cenário 2

\begin{tabular}{|c|c|c|c|c|c|c|}
\hline Objeto de Simulação & Medida de performance & 2.1 & 2.2 & 2.3 & 2.4 & 2.5 \\
\hline \multirow[t]{2}{*}{ Moega 1} & Esperando \% & 41 & 100 & 69 & 70 & 81 \\
\hline & Trabalhando \% & 59 & 0 & 31 & 30 & 19 \\
\hline \multirow[t]{2}{*}{ Moega 2} & Esperando \% & 41 & 4 & 14 & 12 & 2 \\
\hline & Trabalhando \% & 59 & 96 & 86 & 88 & 98 \\
\hline \multirow[t]{2}{*}{ Moega 3} & Esperando \% & 28 & 35 & 29 & 28 & 29 \\
\hline & Trabalhando \% & 72 & 65 & 71 & 72 & 71 \\
\hline \multirow[t]{2}{*}{ Moega 4} & Esperando \% & 28 & 35 & 29 & 28 & 29 \\
\hline & Trabalhando \% & 72 & 65 & 71 & 72 & 71 \\
\hline \multirow[t]{2}{*}{ Moega 5} & Esperando \% & 42 & 36 & 40 & 41 & 39 \\
\hline & Trabalhando \% & 58 & 64 & 60 & 59 & 61 \\
\hline \multirow[t]{2}{*}{ Moega 6} & Esperando \% & 42 & 36 & 40 & 41 & 39 \\
\hline & Trabalhando \% & 58 & 64 & 60 & 59 & 61 \\
\hline \multirow[t]{2}{*}{ Moega 7} & Esperando \% & 66 & 69 & 67 & 67 & 68 \\
\hline & Trabalhando \% & 34 & 31 & 33 & 33 & 32 \\
\hline \multirow[t]{2}{*}{ Moega 8} & Esperando \% & 17 & 69 & 24 & 20 & 27 \\
\hline & Trabalhando \% & 83 & 31 & 76 & 80 & 73 \\
\hline \multirow[t]{2}{*}{ 1a Liberação do veículo } & Esperando \% & 1 & 9 & 2 & 1 & 1 \\
\hline & Trabalhando \% & 99 & 80 & 98 & 99 & 98 \\
\hline \multirow[t]{2}{*}{ 2a Liberação do veículo } & Esperando \% & 54 & 65 & 55 & 54 & 55 \\
\hline & Trabalhando \% & 46 & 35 & 45 & 46 & 45 \\
\hline \multirow[t]{2}{*}{ 3a Liberação do veículo } & Esperando \% & 16 & 7 & 12 & 14 & 11 \\
\hline & Trabalhando \% & 84 & 93 & 88 & 86 & 89 \\
\hline \multirow[t]{2}{*}{ 4a Liberação do veículo } & Esperando \% & 50 & 100 & 57 & 53 & 61 \\
\hline & Trabalhando \% & 50 & 0 & 43 & 47 & 39 \\
\hline \multirow[t]{2}{*}{ Triagem A } & Esperando \% & 13 & 55 & 28 & 16 & 28 \\
\hline & Bloqueado \% & 87 & 45 & 72 & 84 & 72 \\
\hline \multirow[t]{2}{*}{ Triagem G } & Esperando \% & 78 & 28 & 59 & 73 & 62 \\
\hline & Bloqueado \% & 22 & 72 & 41 & 27 & 38 \\
\hline
\end{tabular}

Fonte: Autor (2020).

A moega 1 foi a mais ociosa, menos na situação 2.1. Na situação 2.5 houve a maior utilização das moegas, com a moega 2 tendo chegado a $98 \%$. Na situação 2.2 a moega 1 não teve possibilidade de atender nenhum caminhão devido à restrição de tamanho. As triagens serve somente para direcionar os caminhões para as filas, e por esse motivo ou elas ficam bloqueadas, ou ficam aguardando a liberação.

Este cenário apresenta uma melhora significativa e mais realista em relação ao primeiro cenário, deixando claro a diferença que faz a mudança de trajeto do caminhão. 


\subsection{Análise do cenário 3}

O terceiro cenário é o mais realista, porque no terminal portuário o caminhão é direcionado para a menor fila e pode mudar de trajeto. Este cenário apresenta resultados melhores que o segundo cenário em todas as formas de despacho, chegando a carga total a aumentar de $0,34 \%$ a $6,34 \%$. Os resultados relativos à quantidade de carga transportada são mostrados na tabela 9.

Tabela 9 - Quantidade de carga transportada no cenário 3

\begin{tabular}{|c|c|c|c|c|c|c|}
\hline Objeto de Simulação & Medida de performance & 3.1 & 3.2 & 3.3 & 3.4 & 3.5 \\
\hline Carga Total $(\mathrm{t})$ & Valor & 8.480 .056 & 8.663 .965 & 9.469 .370 & 9.589 .300 & 9.867 .347 \\
\hline Açúcar $(\mathrm{t})$ & Valor & 4.481 .725 & 4.575 .515 & 4.952 .074 & 5.040 .866 & 5.320 .292 \\
\hline Soja $(t)$ & Valor & 3.998 .331 & 4.088 .450 & 4.517 .296 & 4.548 .434 & 4.547 .055 \\
\hline Quantidade de caminhões & Valor & 149.202 & 110.445 & 147.080 & 148.995 & 148.904 \\
\hline Carga de caminhões & Valor & 5.669 .676 & 5.853 .585 & 6.658 .990 & 6.778 .920 & 7.056 .967 \\
\hline Quantidade de vagões & Valor & 33.860 & 33.876 & 33.876 & $\quad 33.876$ & $5 \quad 33.876$ \\
\hline Carga de trens & Valor & 2.810 .380 & 2.810 .380 & 2.810 .380 & 2.810 .380 & 2.810 .380 \\
\hline
\end{tabular}

Fonte: Autor (2020).

A melhor forma de despacho foi a 3.5, mesmo seguindo a ordem das moegas. A quantidade de açúcar é maior do que a quantidade de grãos pelo mesmo motivo já esclarecido nos outros cenários. A quantidade de caminhões foi maior na situação 3.1 e menor na 3.2. A carga dos trens não muda nas situações.

Há uma diferença de 91 caminhões e de 278.047 toneladas de carga transportada entre as formas de despacho 3.4 e 3.5. Isso pode ser explicado pela diferença nos tamanhos dos caminhões com grãos e dos com açúcar. Apesar de o número de caminhões ter sido menor, a quantidade transportada por caminhão foi maior (caminhões de 9 eixos). O número de descargas realizadas nas moegas é exposto na tabela 10 .

Tabela 10 - Número de descargas realizadas no cenário 3 


\begin{tabular}{|c|c|c|c|c|c|c|}
\hline Objeto de Simulação & Medida de performance & 3.1 & 3.2 & 3.3 & 3.4 & 3.5 \\
\hline Moega 1 & Número de trabalhos concluídos & 21.550 & 0 & 11.132 & 10.748 & 6.922 \\
\hline Moega 2 & Número de trabalhos concluídos & 21.391 & 34.529 & 31.020 & 32.151 & 35.865 \\
\hline Moega 3 & Número de trabalhos concluídos & 25.927 & 20.372 & 25.532 & 25.896 & 25.927 \\
\hline Moega 4 & Número de trabalhos concluídos & 25.929 & 20.371 & 25.540 & 25.898 & 25.933 \\
\hline Moega 5 & Número de trabalhos concluídos & 25.846 & 27.365 & 25.872 & 26.202 & 26.202 \\
\hline Moega 6 & Número de trabalhos concluídos & 25.846 & 27.364 & 25.871 & 26.201 & 26.202 \\
\hline Moega 7 & Número de trabalhos concluídos & 9.205 & 7.143 & 9.116 & 9.139 & 9.148 \\
\hline Moega 8 & Número de trabalhos concluídos & 27.384 & 7.177 & 26.873 & 26.636 & 26.581 \\
\hline Final & Número de trabalhos concluídos & 183.076 & 144.320 & 180.957 & 182.873 & 182.780 \\
\hline
\end{tabular}

Fonte: Autor (2020).

A situação 3.1 foi a que melhor aproveitou a moega 1 em virtude da restrição de tamanho dos caminhões, e as diferenças entre as moegas foram as menores. $\mathrm{Na}$ situação 3.2 a moega 1 não foi utilizada e as moegas 7 e 8 somente foram utilizadas pelos trens. A moega 2 foi a mais utilizada por não ter conexão com os trens nem restrição de tamanho. A maior diferença foi observada entre as formas de despacho $3.3,3.4$ e 3.5, relativa à quantidade de caminhões nas moegas 1 e 2 . Apesar de nas formas de despacho 3.3 e 3.4 a moega 1 ter sido mais utilizada do que na 3.5, a maior utilização da moega 2 na situação 3.5 compensou essa diferença e fez que essa situação fosse o melhor. O tempo das filas no sistema é apresentado na tabela 11.

Tabela 11 - Tempo médios das filas dos caminhões no cenário 3

\begin{tabular}{|c|c|c|c|c|c|c|}
\hline Objeto de Simulação & Medida de performance & 3.1 & 3.2 & 3.3 & 3.4 & 3.5 \\
\hline Tempo médio no sistema (min) & Tempo médio no sistema & 600 & 756 & 608 & 602 & 606 \\
\hline Tempo médio da Fila 1 (min) & Tempo médio no sistema & 142 & 112 & 150 & 142 & 143 \\
\hline Tempo médio da Fila 2 ( $\mathrm{min}$ ) & Tempo médio no sistema & 111 & 91 & 120 & 112 & 112 \\
\hline Tempo médio da Fila 3 (min) & Tempo médio no sistema & 93 & 94 & 92 & 82 & 82 \\
\hline Tempo médio da Fila 4 (min) & Tempo médio no sistema & 84 & 0 & 85 & 92 & 91 \\
\hline \multirow[t]{2}{*}{ Fila do pátio } & Tempo médio no sistema & 264 & 404 & 266 & 266 & 266 \\
\hline & Tamanho médio da fila & 76 & 86 & 75 & 76 & 76 \\
\hline Fila da Recepção & Tempo médio no sistema & 35 & 47 & 34 & 35 & 35 \\
\hline
\end{tabular}

Fonte: Autor (2020).

Neste cenário, em comparação com o segundo, o tempo diminuiu 4 minutos entre as situações 2.2 e 3.2 e 40 minutos entre as situações 2.5 e 3.5 . Além disso, as variações do tempo médio das filas são as menores, reflexo dos direcionamentos dos caminhões. É importante destacar também que as filas de grãos são menores do que as filas de açúcar, o que pode ser explicado pelo menor tempo de descarga dos caminhões com grãos em comparação aos caminhões com açúcar. 
A quantidade de caminhões no pátio diminui, uma vez que eles são alocados de uma forma melhor do que no segundo cenário. A porcentagem de trabalho, espera e bloqueio no sistema é apresentada na tabela 12 .

Tabela 12 - Porcentagem de trabalho, espera e bloqueio no cenário 3

\begin{tabular}{|c|c|c|c|c|c|c|}
\hline Objeto de Simulação & Medida de performance & 3.1 & 3.2 & 3.3 & 3.4 & 3.5 \\
\hline \multirow[t]{2}{*}{ Moega 1} & Esperando \% & 41 & 100 & 70 & 71 & 81 \\
\hline & Trabalhando\% & 59 & 0 & 30 & 29 & 19 \\
\hline \multirow[t]{2}{*}{ Moega 2} & Esperando \% & 42 & 6 & 15 & 12 & 2 \\
\hline & Trabalhando\% & 58 & 94 & 85 & 88 & 98 \\
\hline \multirow[t]{2}{*}{ Moega 3} & Esperando \% & 22 & 34 & 23 & 22 & 22 \\
\hline & Trabalhando \% & 78 & 66 & 77 & 78 & 78 \\
\hline \multirow[t]{2}{*}{ Moega 4} & Esperando \% & 22 & 34 & 23 & 22 & 22 \\
\hline & Trabalhando \% & 78 & 66 & 77 & 78 & 78 \\
\hline \multirow[t]{2}{*}{ Moega 5} & Esperando \% & 39 & 36 & 39 & 39 & 39 \\
\hline & Trabalhando\% & 61 & 64 & 61 & 61 & 61 \\
\hline \multirow[t]{2}{*}{ Moega 6} & Esperando \% & 39 & 36 & 39 & 38 & 38 \\
\hline & Trabalhando\% & 61 & 64 & 61 & 62 & 62 \\
\hline \multirow[t]{2}{*}{ Moega 7} & Esperando \% & 64 & 69 & 64 & 64 & 64 \\
\hline & Trabalhando\% & 36 & 31 & 36 & 36 & 36 \\
\hline \multirow[t]{2}{*}{ Moega 8} & Esperando \% & 14 & 69 & 15 & 16 & 16 \\
\hline & Trabalhando\% & 86 & 31 & 85 & 84 & 84 \\
\hline \multirow[t]{2}{*}{ 1a Liberação do veículo } & Esperando \% & 2 & 13 & 4 & 2 & 2 \\
\hline & Trabalhando\% & 98 & 79 & 96 & 98 & 98 \\
\hline \multirow[t]{2}{*}{ 2a Liberação do veículo } & Esperando \% & 45 & 64 & 46 & 45 & 45 \\
\hline & Trabalhando\% & 55 & 36 & 54 & 55 & 55 \\
\hline \multirow[t]{2}{*}{ 3a Liberação do veículo } & Esperando \% & 11 & 6 & 11 & 10 & 10 \\
\hline & Trabalhando\% & 89 & 94 & 89 & 90 & 90 \\
\hline \multirow[t]{2}{*}{ 4ª Liberação do veículo } & Esperando \% & 45 & 100 & 46 & 47 & 47 \\
\hline & Trabalhando \% & 55 & 0 & 54 & 53 & 53 \\
\hline \multirow[t]{2}{*}{ Triagem A } & Esperando \% & 33 & 67 & 36 & 33 & 34 \\
\hline & Bloqueado \% & 67 & 33 & 64 & 67 & 66 \\
\hline \multirow[t]{2}{*}{ Triagem G } & Esperando \% & 60 & 22 & 61 & 60 & 61 \\
\hline & Bloqueado \% & 40 & 78 & 39 & 40 & 39 \\
\hline
\end{tabular}

Fonte: Autor (2020).

A moega 1 continua a ser a mais ociosa em quase todas as situações, com exceção da situação 3.1 , em que a moega 7 é a mais inativa. A situação 3.2 é muito parecida com a situação 2.2. Nas situações 3.3, 3.4 e 3.5 percebe-se que a moega 2 é a que mais trabalha.

Este cenário é o mais realista, mostrando que o agendamento e o despacho dos caminhões do pátio têm influência na quantidade de toneladas transportadas através do terminal. 


\subsection{Análise do cenário 4}

A diferença da carga total do terceiro cenário para o quarto cenário é pequena. Na primeira forma de despacho a carga diminuiu 2052 toneladas $(0,02 \%)$, na segunda aumentou 17702 toneladas $(0,2 \%)$, na terceira aumentou 8774 toneladas $(0,09 \%)$, na quarta aumentou 3028 toneladas $(0,03 \%)$ e na quinta diminuiu 1111 toneladas $(0,01 \%)$. Os resultados relativos à quantidade de carga transportada são apresentados na tabela 13.

Tabela 13 - Quantidade de carga transportada no cenário 4

\begin{tabular}{|c|c|c|c|c|c|c|}
\hline Objeto de Simulação & Medida de performance & 4.1 & 4.2 & 4.3 & 4.4 & 4.5 \\
\hline Carga Total $(\mathrm{t})$ & Valor & 8.478 .004 & 8.681 .667 & 9.478 .144 & 9.592 .328 & 9.866 .236 \\
\hline Açúcar $(t)$ & Valor & 4.480 .699 & 4.584 .472 & 4.956 .487 & 5.042 .778 & 5.320 .023 \\
\hline Soja $(t)$ & Valor & 3.997 .305 & 4.097 .195 & 4.521 .657 & 4.549 .550 & 4.546 .213 \\
\hline Quantidade de caminhões & Valor & 149.148 & 110.779 & 147.273 & 149.081 & 148.872 \\
\hline Carga de caminhões & Valor & 5.667 .624 & 5.871 .287 & 6.667 .764 & 6.781 .948 & 7.055 .856 \\
\hline Quantidade de vagões & Valor & 33.860 & 33.860 & 33.860 & 33.860 & 33.860 \\
\hline Carga de trens & Valor & 2.810 .380 & 2.810 .380 & 2.810 .380 & 2.810 .380 & 2.810 .380 \\
\hline
\end{tabular}

Fonte: Autor (2020).

A melhor forma de despacho continua sendo a quinta. A quantidade de açúcar é maior do que a quantidade de grãos pelos mesmos motivos explicitados nos outros cenários. A quantidade de caminhões foi maior na situação 4.1, no entanto a diferença dessa situação para as situações 4.4 e 4.5 foi pequena. A menor quantidade de caminhões foi observada na situação 4.2. A carga dos trens não se altera nas situações.

Entre as situações 4.4 e 4.5 há uma diferença de 209 caminhões e de 273.908 toneladas de carga transportada. Assim como no cenário 3 , o que explica essas diferenças é o tamanho dos caminhões. O número de descargas realizadas nas moegas é mostrado na tabela 14 .

Tabela 14 - Número de descargas realizadas no cenário 4 


\begin{tabular}{|c|c|c|c|c|c|c|}
\hline Objeto de Simulação & Medida de performance & 4.1 & 4.2 & 4.3 & 4.4 & 4.5 \\
\hline Moega 1 & Número de trabalhos concluídos & 21.547 & 0 & 11.111 & 10.864 & 6.862 \\
\hline Moega 2 & Número de trabalhos concluídos & 21.384 & 34.543 & 31.067 & 32.069 & 35.900 \\
\hline Moega 3 & Número de trabalhos concluídos & 25.918 & 20.446 & 25.572 & 25.903 & 25.935 \\
\hline Moega 4 & Número de trabalhos concluídos & 25.921 & 20.452 & 25.572 & 25.903 & 25.935 \\
\hline Moega 5 & Número de trabalhos concluídos & 25.766 & 27.447 & 25.798 & 25.893 & 26.110 \\
\hline Moega 6 & Número de trabalhos concluídos & 25.766 & 27.447 & 25.798 & 25.893 & 26.110 \\
\hline Moega 7 & Número de trabalhos concluídos & 9.156 & 7.143 & 9.104 & 9.107 & 9.082 \\
\hline Moega 8 & Número de trabalhos concluídos & 27.566 & 7.177 & 27.127 & 27.325 & 26.814 \\
\hline Final & Número de trabalhos concluídos & 183.025 & 144.656 & 181.151 & 182.957 & 182.747 \\
\hline
\end{tabular}

Fonte: Autor (2020).

A situação 4.1 foi a que mais utilizou a moega 1 entre todas as situações. $\mathrm{Na}$ situação 4.2 a moega 1 não foi utilizada e as moegas 7 e 8 foram utilizadas somente pelos trens. A maior diferença entre as situações 4.3, 4.4 e 4.5 foram as quantidades de caminhões nas moegas 1 e 2. Apesar de nas situações 4.3 e 4.4 a moega 1 ter sido mais utilizada do que na situação 4.5 , a maior utilização da moega 2 na situação 4.5 compensou essa diferença e fez que essa situação fosse a melhor, tal como no terceiro cenário. A carga total nas situações 4.3 e 4.4 , respectivamente, é de 9.478.144 e 9.592.328, e a carga total na situação 4.5 é de 9.866.236. O tempo das filas no sistema é apresentado na tabela 15.

Tabela 15 - Tempo médios das filas dos caminhões no cenário 4

\begin{tabular}{|c|c|c|c|c|c|c|}
\hline Objeto de Simulação & Medida de performance & 4.1 & 4.2 & 4.3 & 4.4 & 4.5 \\
\hline Tempo médio no sistema (min) & Tempo médio no sistema & 600 & 754 & 607 & 602 & 606 \\
\hline Tempo médio da Fila 1 (min) & Tempo médio no sistema & 142 & 109 & 150 & 142 & 143 \\
\hline Tempo médio da Fila 2 ( $\mathrm{min}$ ) & Tempo médio no sistema & 112 & 88 & 120 & 112 & 113 \\
\hline Tempo médio da Fila 3 (min) & Tempo médio no sistema & 93 & 94 & 92 & 83 & 82 \\
\hline Tempo médio da Fila 4 (min) & Tempo médio no sistema & 84 & 0 & 84 & 89 & 89 \\
\hline \multirow[t]{2}{*}{ Fila do pátio } & Tempo médio no sistema & 170 & 276 & 166 & 168 & 170 \\
\hline & Tamanho médio da fila & 49 & 59 & 47 & 48 & 49 \\
\hline Fila da Recepção & Tempo médio no sistema & 35 & 47 & 33 & 35 & 35 \\
\hline
\end{tabular}

Fonte: Autor (2020).

O tempo do sistema é parecido com o seu correspondente no terceiro cenário. Nas situações 4.4 e 4.5 as filas de grãos são menores do que as filas de açúcar, tal como no terceiro cenário. A fila no pátio diminui porque os caminhões são alocados pelo "organizador". Quando eles entram no organizador, fisicamente eles ainda estão no pátio; no entanto, isso não é levado em conta devido às restrições do sistema. 
Apesar disso, em comparação com o cenário 3, o tempo médio no sistema não muda. A porcentagem de trabalho, espera e bloqueio no sistema é exposta na tabela 16.

Tabela 16 - Porcentagem de trabalho, espera e bloqueio no cenário 4

\begin{tabular}{|c|c|c|c|c|c|c|}
\hline Objeto de Simulação & Medida de performance & 4.1 & 4.2 & 4.3 & 4.4 & 4.5 \\
\hline \multirow[t]{2}{*}{ Moega 1} & Esperando \% & 41 & 100 & 70 & 70 & 81 \\
\hline & Trabalhando\% & 59 & 0 & 30 & 30 & 19 \\
\hline \multirow[t]{2}{*}{ Moega 2} & Esperando \% & 42 & 6 & 15 & 12 & 2 \\
\hline & Trabalhando\% & 58 & 94 & 85 & 88 & 98 \\
\hline \multirow[t]{2}{*}{ Moega 3} & Esperando \% & 22 & 34 & 23 & 22 & 22 \\
\hline & Trabalhando\% & 78 & 66 & 77 & 78 & 78 \\
\hline \multirow[t]{2}{*}{ Moega 4} & Esperando \% & 22 & 34 & 23 & 22 & 22 \\
\hline & Trabalhando\% & 78 & 66 & 77 & 78 & 78 \\
\hline \multirow[t]{2}{*}{ Moega 5} & Esperando \% & 40 & 36 & 39 & 39 & 39 \\
\hline & Trabalhando\% & 60 & 64 & 61 & 61 & 61 \\
\hline \multirow[t]{2}{*}{ Moega 6} & Esperando \% & 40 & 36 & 39 & 39 & 39 \\
\hline & Trabalhando\% & 60 & 64 & 61 & 61 & 61 \\
\hline \multirow[t]{2}{*}{ Moega 7} & Esperando \% & 64 & 69 & 64 & 64 & 64 \\
\hline & Trabalhando \% & 36 & 31 & 36 & 36 & 36 \\
\hline \multirow[t]{2}{*}{ Moega 8} & Esperando \% & 13 & 69 & 15 & 14 & 16 \\
\hline & Trabalhando\% & 87 & 31 & 85 & 86 & 84 \\
\hline \multirow[t]{2}{*}{ 1a Liberação do veículo } & Esperando \% & 2 & 13 & 4 & 2 & 2 \\
\hline & Trabalhando\% & 98 & 79 & 96 & 98 & 98 \\
\hline \multirow[t]{2}{*}{ 2a Liberação do veículo } & Esperando \% & 45 & 63 & 46 & 45 & 45 \\
\hline & Trabalhando\% & 55 & 37 & 54 & 55 & 55 \\
\hline \multirow[t]{2}{*}{ 3a Liberação do veículo } & Esperando \% & 12 & 6 & 12 & 11 & 11 \\
\hline & Trabalhando\% & 88 & 94 & 88 & 89 & 89 \\
\hline \multirow[t]{2}{*}{4 Liberação do veículo } & Esperando \% & 45 & 100 & 46 & 45 & 47 \\
\hline & Trabalhando\% & 55 & 0 & 54 & 55 & 53 \\
\hline \multirow[t]{2}{*}{ Triagem A } & Esperando \% & 33 & 69 & 36 & 34 & 33 \\
\hline & Bloqueado \% & 67 & 31 & 64 & 66 & 67 \\
\hline \multirow[t]{2}{*}{ Triagem G } & Esperando \% & 59 & 22 & 61 & 61 & 61 \\
\hline & Bloqueado \% & 41 & 78 & 39 & 39 & 39 \\
\hline
\end{tabular}

Fonte: Autor (2020).

A moega 1 ainda continua a ser a mais ociosa em quase todas as situações. Nas situações 4.3, 4.4 e 4.5, percebe-se que a moega 8 é a mais utilizada. Observa-se que na situação 4.5 a moega 8 e a 2 se igualam quanto ao trabalho efetuado. Nessas situações houve um aumento na utilização das moegas e na liberação dos veículos 1 e 3, o que evidencia a influência dos trens, já que eles não percorrem esse caminho.

Este cenário, apesar de apresentar os melhores resultados em algumas formas de despacho, difere muito pouco do terceiro cenário, o que indica que o sistema é importante como um todo. A possibilidade de mudança de trajeto pelo caminhão, o direcionamento deste para a menor fila e a ordem de despacho foram os fatores decisivos para a otimização do sistema. 


\subsection{Análise dos cenários}

Foram analisadas todas as informações geradas nas simulações das etapas de validação e dos cenários (1, 2, 3 e 4), com base nos dados fornecidos pela empresa. $A$ capacidade do terminal portuário, informada pela empresa, serviu de referência para a modelagem do sistema.

Pode-se concluir que, no tocante à operação desse sistema, a situação 3.5 é a melhor para transportar grãos, com um total de 9.867 .347 toneladas. Nesta situação o caminhão é direcionado para a menor fila. Ele é alocado para outra fila com a chegada dos trens e a ordem de despacho se dá de acordo com a ordem das moegas. É a melhor situação, se comparada à situação 3.3, em que a ordem de despacho não segue nenhuma regra, e na qual houve o transporte de 9.469 .370 toneladas $(4,2 \%$ a menos que na situação 3.5). A tabela 17 a seguir mostra os 6 melhores resultados obtidos com a simulação.

Tabela 17 - Seis melhores situações

\begin{tabular}{|c|c|c|c|c|c|c|c|}
\hline Objeto de Simulação & Medida de performance & 3.3 & 4.3 & 3.4 & 4.4 & 4.5 & 3.5 \\
\hline Carga Total $(t)$ & Valor & 9.469 .370 & 9.478 .144 & 9.589 .300 & 9.592 .328 & 9.866 .236 & 9.867 .347 \\
\hline Açúcar (t) & Valor & 4.952 .074 & 4.956 .487 & 5.040 .866 & 5.042 .778 & 5.320 .023 & 5.320 .292 \\
\hline Soja (t) & Valor & 4.517.296 & 4.521 .657 & 4.548 .434 & 4.549 .550 & 4.546 .213 & 4.547 .055 \\
\hline \multicolumn{2}{|c|}{ Quantidade de caminhões Valor } & 147.080 & 147.273 & 148.995 & 149.081 & 148.872 & 148.904 \\
\hline Carga de caminhões & Valor & 6.658 .990 & 6.667 .764 & 6.778 .920 & 6.781 .948 & 7.055 .856 & 7.056 .967 \\
\hline Quantidade de vagões & Valor & 33.876 & 33.860 & 33.876 & 33.860 & 33.860 & 33.876 \\
\hline Carga de trens & Valor & 2.810 .380 & 2.810 .380 & 2.810 .380 & 2.810 .380 & 2.810 .380 & 2.810 .380 \\
\hline Moega 1 & Número de trabalhos concluídos & 11132 & 11111 & 10748 & 10864 & 6862 & 6922 \\
\hline Moega 2 & Número de trabalhos concluídos & 31020 & 31067 & 32151 & 32069 & 35900 & 35865 \\
\hline Moega 3 & Número de trabalhos concluídos & 25532 & 25572 & 25896 & 25903 & 25935 & 25927 \\
\hline Moega 4 & Número de trabalhos concluídos & 25540 & 25572 & 25898 & 25903 & 25935 & 25933 \\
\hline Moega 5 & Número de trabalhos concluídos & 25872 & 25798 & 26202 & 25893 & 26110 & 26202 \\
\hline Moega 6 & Número de trabalhos concluídos & 25871 & 25798 & 26201 & 25893 & 26110 & 26202 \\
\hline Moega 7 & Número de trabalhos concluídos & 9116 & 9104 & 9139 & 9107 & 9082 & 9148 \\
\hline Moega 8 & Número de trabalhos concluídos & 26873 & 27127 & 26636 & 27325 & 26814 & 26581 \\
\hline Final & Número de trabalhos concluídos & 180957 & 181151 & 182873 & 182957 & 182747 & 182780 \\
\hline
\end{tabular}

Fonte: Autor (2020).

Analisando-se a tabela, pode-se perceber que apesar de a situação 4.5 (com o organizador) não apresentar o melhor resultado, a diferença é pequena em relação à situação 3.5. No entanto, comparando-se as outras formas de despacho, os resultados 
com o cenário 4 são melhores que aqueles com o cenário 3 , a saber, nas situações 4.3 e 4.4 , em comparação com as situações 3.3 e 3.4 . 


\subsection{Validação do modelo}

As informações fornecidas pelo terminal portuário foram analisadas e utilizadas para a validação do modelo. Como o terminal portuário não tem controle sobre os fluxos dos trens, somente foram analisados os dados dos caminhões na validação do modelo. Foi definida (com base nos dados fornecidos) a quantidade de caminhões por ano necessária para que a análise fosse realizada, portanto o período observado foi de um ano. A tabela 18 apresenta os resultados da validação.

Com relação ao terminal portuário, os resultados analisados foram os seguintes:

- Tempo médio dos caminhões nas filas;

- Número de caminhões atendidos;

- Total de grãos descarregados pelos caminhões;

- Total de grãos descarregados pelos caminhões em cada moega.

Tabela 18 - Resultados da validação

\begin{tabular}{c|cccc} 
& Modelo & Real & $\begin{array}{c}\text { Diferença } \\
\text { Absoluta }\end{array}$ & $\begin{array}{c}\text { Diferença } \\
\text { Percentual }\end{array}$ \\
\hline Total Caminhões Atendidos & $196.817,00$ & $196.224,00$ & 593,00 & $0,302 \%$ \\
Toneladas de Açúcar & $4.609 .559,50$ & $4.754 .727,25$ & $-145.167,75$ & $-3,053 \%$ \\
Toneladas de Grãos & $4.345 .614,00$ & $4.278 .092,00$ & $67.522,00$ & $1,578 \%$ \\
\hline Caminhões Atendidos na Moega1 & 10.886 & 11.242 & -356 & $-3,167 \%$ \\
Caminhões Atendidos na Moega2 & 32.759 & 33.726 & -967 & $-2,867 \%$ \\
Caminhões Atendidos na Moega3 & 28.832 & 29.894 & -1.062 & $-3,553 \%$ \\
Caminhões Atendidos na Moega4 & 28.832 & 29.638 & -806 & $-2,719 \%$ \\
Caminhões Atendidos na Moega5 & 29.050 & 28.872 & 178 & $0,617 \%$ \\
Caminhões Atendidos na Moega6 & 29.049 & 28.361 & 688 & $2,426 \%$ \\
Caminhões Atendidos na Moega7 & 37.409 & 36.792 & 617 & $1,677 \%$ \\
\hline
\end{tabular}

Fonte: Autor (2020).

Como pode ser observado nos resultados comparativos, a diferença entre os resultados do modelo e do real foi menor que $4 \%$ para todos os resultados, tendo a maior diferença sido de 3,55\%, na moega 3. Portanto, após verificação dos resultados com o terminal portuário, pode-se considerar validado o modelo desenvolvido para representar o sistema desse terminal. 


\section{CONCLUSÕES E RECOMENDAÇÕES}

Esta pesquisa tratou de uma abordagem de simulação utilizada para realizar a análise de possíveis estratégias operacionais em um terminal portuário.

Com a finalidade de estudar as decisões operacionais que maximizem as atividades de um sistema de recebimento de grãos, o objetivo principal foi atingido. Construiu-se um modelo de simulação representativo de um terminal portuário pelo qual são transportados açúcar e grãos, o estudo da sua operação virtual por meio da técnica de simulação computacional possibilitou entender algumas práticas que podem aumentar a capacidade de exportação.

Com relação aos objetivos específicos, foram analisadas técnicas de simulação. O modelo de simulação desenvolvido representou o terminal portuário. Através desse modelo foi verificada a oferta de grãos deste terminal portuário.

No capítulo 3 foi demonstrado o sistema de recebimento do terminal portuário. O modelo de simulação construído utilizou a técnica de simulação discreta, como visto no capítulo 5. Dessa forma, conclui-se que é possível utilizar a simulação de eventos discretos para simular o sistema de estudo.

O estudo tornou possível a avaliação da oferta do terminal portuário, pois o modelo abrangia desde a entrada no pátio regulador até o descarregamento dos caminhões. Para estudos futuros pode-se considerar a possibilidade de incluir no modelo o transporte dos grãos para os armazéns e então dos armazéns para os navios.

Com base nos cenários criados foi possível comparar diversas formas de operação do terminal portuário, formas de despacho, organizações de filas, assim como a influência "organizador" sobre o sistema. Também foi possível avaliar esses cenários através da quantidade escoada de grãos, de açúcar e da ocupação das moegas do terminal.

Por meio do estudo de simulação utilizando o modelo desenvolvido, foi possível determinar a oferta do terminal portuário nos diversos cenários. Apesar de ser difícil controlar a forma de despacho dos caminhões, esse controle tem uma influência no rendimento global do sistema. O modelo de simulação se apresenta como uma ferramenta para o processo de tomada de decisão nesse sistema, ajudando o profissional responsável no terminal portuário a entender melhor as opções existentes. 
Nesses cenários criados não foram considerados os armazéns e o transporte para os navios, pois o foco do trabalho era maximizar a capacidade do terminal portuário para suprir a demanda com facilidade. No entanto, as chegadas dos navios têm muita influência sobre o fluxo do terminal, gerando uma parcela de incerteza no modelo. Desse modo, pode ser considerada uma sugestão de estudo futuro a criação de um modelo que considere as chegadas dos navios.

Outras sugestões de análise e pesquisa também podem ser depreendidas do estudo, como: a influência da incerteza na confiabilidade da quantificação dos fluxos do terminal (ou seja, considerar as possibilidades de algo ocorrer e prejudicar a operação) e a investigação da influência do aumento da variabilidade da oferta de grãos (produtos derivados de produção agrícola têm naturalmente uma variação de oferta).

A simulação criada figura como uma ferramenta de grande utilidade para o processo de tomada de decisão na gestão do terminal, visto que demonstra as restrições operacionais, garantindo assim um melhor planejamento. Desta forma, ter acesso a essa ferramenta auxilia no estudo de soluções para o terminal portuário. $O$ modelo de simulação útil para este estudo, pois tem capacidade de reproduzir soluções rápidas e confiáveis para problemas relacionados a portos. Além disso, o modelo de simulação possui flexibilidade para a variação de cenários, fornecendo, ao analista, suporte para testar as mais diversas combinações de variáveis, o que seria muito mais difícil em um modelo determinista. 


\section{REFERÊNCIAS BIBLIOGRÁFICAS}

ANTAQ. (2018) Anuário 2017. Brasilia, 2018. Obtido de http://portal.antaq.gov.br/

ANTAQ. (2020) Movimentação Portuária. Obtido 25 de maio de 2020, de http://web.antaq.gov.br/ANUARIO/

Arango, C., Cortés, P., Muñuzuri, J., e Onieva, L. (2011) Berth allocation planning in Seville inland port by simulation and optimisation. Advanced Engineering Informatics, 25(3), 452-461. doi:10.1016/j.aei.2011.05.001

Arenales, M., Armentano, V., Morabito, R., e Yanasse, H. (2007) Pesquisa Operacional. (Elsevier, Ed). Rio de Janeiro.

Ballou, R. H. (2006) Gerenciamento da Cadeia de Suprimentos/ Logística Empresarial. (BOOKMAN, Ed) (5a Edição.). São Paulo.

Banks, J., Carson II, J., Nelson, B. L., e Nicol, D. M. (2005) Discrete - Event System Simulation. (4. ed.). Prentice Hall, New Jersey:

Banks, J., e Gibson, R. (1997) Don't simulate when... 10 Rules for determining when simulation is not appropriate. IIE solutions, 29, 30-33.

Brasil, A. T. (2012) Elog e prefeitura de Cubatão ( SP ) desenvolvem centro de pesquisas ambientais. Obtido 9 de abril de 2019, de http://www.transportabrasil.com.br/2012/06/elog-e-prefeitura-de-cubatao-sp-desenvolvemcentro-de-pesquisas-ambientais/

Bressman, L. H., Browne, J. J., Nanninga, C. L., e Weintrob, B. (1978) Financial simulation model: Assessing project risk at the Port Authority of New York and New Jersey. Proceedings of the 10th conference on Winter simulation, V. 2, 955-96.

Brito, T. B. (2009) Modelagem e simulação de um terminal regulador de contêineres. XXIX Encontro Nacional de Engenharia de Produção.

Carvalho, L. B. D. E. (2005) Transporte Rodoviário do Açúcar para Exportação no Estado de São Paulo. Universidade de São Paulo.

Chwif, L., e Medina, A. (2014) Modelagem e simulação de eventos discretos. (4a edição:). Elsevier Brasil.

Cimpeanu, R., Devine, M. T., e O'Brien, C. (2017) A simulation model for the management and expansion of extended port terminal operations. Transportation Research Part E: Logistics and Transportation Review, 98, 105-131. doi:10.1016/j.tre.2016.12.005

CODESP. Estabelece regramento para o acesso terrestre ao porto de santos. (2014).

CODESP. (2015) Porto de Santos. Obtido 1 de abril de 2019, de http://www.portodesantos.com.br/institucional/o-porto-de-santos/ 
CODESP. (2016) Plano de Desenvolvimento e Zoneamento Porto de Santos., 1-179.

Colavite, A. S., e Konishi, F. (2015) A matriz do transporte no Brasil : uma análise comparativa para a competitividade. XII SEGeT - Simpósio de Excelência em Gestão e Tecnologia.

Collie, P. I. (1975) A simulation model for port management training. The Dock \& Harbour Authority, v. 55, n.

Collier, P. I. (1980) Simulation as an aid to the study of a port as a system. Ship Operation Automation, v. 3, 51-6.

Collier, P. I., e Litherland, M. (1979) Port productivity: improvements in ship loading performance using causality models. Dock and Harbour Authority, v. 60, n.

Cortés, P., Muñuzuri, J., Nicolás Ibáñez, J., e Guadix, J. (2007) Simulation of freight traffic in the Seville inland port. Simulation Modelling Practice and Theory, 15(3), 256-271. doi:10.1016/j.simpat.2006.11.004

Demirci, E. (2003) Simulation Modelling and Analysis of a Port Investment. Simulation, 79(2), 94-105. doi:10.1177/0037549703254523

Dragović, B., Tzannatos, E., e Park, N. K. (2017) Simulation modelling in ports and container terminals: literature overview and analysis by research field, application area and tool. Flexible Services and Manufacturing Journal, 29(1), 4-34. doi:10.1007/s10696-016-9239-5

Ecker J.G., e Kupferschmid, M. (1988) Introduction to operations research. Krieger Publishing Company, New York.

FGV. (2006) Relatório Sobre Fiscalização da Regulação Econômico-Financeira Setor Portuário.

Frankel, E. G., Wilmes, P. G., e Chelst., K. G. (1973) Simulation of Multipurpose Port and Multiport Offshore Facilities. Offshore Technology Conference.

Gaban, A. C., e Guarnieri, P. (2015) Identificação de gargalos na Logística Agroindustrial: Revisão Sistemática de Literatura. Congresso da Sociedade Brasileira de Economia, Administração e Sociologia Rural, (May 2017).

Gavira, M. D. O. (2003) Simulação computacional como uma ferramenta de aquisição de conhecimento. Universidade de São Carlos.

Goldratt, E. M., e Cox, J. (2006) A meta: um processo de aprimoramento contínuo. (NBL Editora, Ed) (2 ed.).

Hassan, S. A. (1993) Port Activity Simulation: An Overview. ACM SIGSIM Simulation Digest, v. 23, n., 17-36.

Hillier, F. S., e Lieberman, G. J. (2006) Introduçao à Pesquisa Operacional. (McGraw-Hil.). São Paulo.

Julia, A. F., e Botter, R. C. (2009) Desenvolvimento De Um Modelo De Simulação Para 
Dimensionamento De Um Sistema Integrado Pátio-Porto Na Cadeia Do Minério De Ferro ., (2005), 1-15.

Keedi, S., e Mendonça, P. ; (2000) Trnasportes e seguros no comércio exterior. (Aduaneiras,

Ed). Obtido de https://cursosnocd.com.br/logistica/estrutura-portuaria.htm

Kia, M., Shayan, E., e Ghotb, F. (2002) Investigation of port capacity under a new approach by computer simulation. Computers and Industrial Engineering, 42(2-4), 533-540. doi:10.1016/S0360-8352(02)00051-7

Koh, P. H., Goh, J. L. K., Ng, H. S., e Ng, H. C. (1994) Using simulation to preview plans of a container port operations. Winter Simulation Conference Proceedings, 1109-1115. doi:10.1109/wsc.1994.717496

Lacerda, S. M. (2005) Investimentos nos portos brasileiros: oportunidade da concessão da infra-estrutura portuária. (B. N. de D. E. e Social, Ed). Rio de Janeiro. doi:10.1017/CBO9781107415324.004

Law, A. M., e Kelton, W. D. (1991) Simulation modeling e analysis. (McGraw-Hill, Ed) (3th ed.). New York.

Luo, M., e Grigalunas, T. A. (2003) A spatial-economic multimodal transportation simulation model for US coastal container ports. Maritime Economics and Logistics, 5(2), 158-178. doi:10.1057/palgrave.mel.9100067

McCall, D. C. (1989) Discrete event simulation of oil terminal and port activity. 1989 SCS Western Multiconference.

Melício, R. K. I. S. D. C. (2018) Pátio Regulador na Ótica do Usuário. CITEG Congresso Internacional de Tecnologia e Gestão.

Monteiro, E. A. D. F. (2015) Avaliação do processo de agendamento de caminhões transportadores de granéis sólidos vegetais para acesso aos terminais portuários: o caso porto de santos. Biomass Chem Eng, 49(23-6), 22-23.

Neto, L. R. de C. (2006) Modelagem e Simulação da Cadeia Produtiva do Minério De Ferro. Escola Politécnica da Universidade de São Paulo.

Netto, J. F., Botter, R. C., e Medina, A. C. (2015) Analysis of capacity associated to levels of service at port terminals using systemic approach and simulation of discrete events. 2015 Winter Simulation Conference (WSC). IEEE, (2015), 779-790.

Neves, C. das, e Ignacio, A. A. V. (2010) Análise Da Confiabilidade De Sistemas Operacionais Através Do Simul8: Caso Da Descarga De Minério De Ferro Num Terminal. Encontro Nacional de Engenharia de Produção.

Oliveira, B. B. (2016) Modelo de filas para análise em um sistema portuário Modelo de. Universidade de Brasília.

Oliveira, C. T. de. (2000) Modernização dos portos. (3 ed.). Aduaneira, São Paulo. 
Palos, M. T., e Souza, A. E. de. (2017) O pátio regulador de caminhões acesso ao porto de santos: atuação dos gestores portuários.

Park, C. S., e Noh., Y. D. (1987) An interactive port capacity expansion simulation model. Engineering costs and production economics, v. 11, n., 109-124.

Park, C. S., e Noh, Y. D. (1987) Port Simulation Model for Bulk Cargo Operations. Simulation, 48(6), 236-246. doi:10.1177/003754978704800605

Pegden, C. D., Shannon, R. E., e Sadowski, R. P. (1995) Introduction to simulation using SIMAN. (McGraw-Hill, Ed) (2nd ed.). New York.

Pratap, S., Daultani, Y., Tiwari, M. K., e Mahanty, B. (2018) Rule based optimization for a bulk handling port operations. Journal of Intelligent Manufacturing, 29(2), 287-311. doi:10.1007/s10845-015-1108-7

Radaceanu, E. (1985) Model for simulation of the railway traffic in the port area. Digital Techniques in Simulation, Communication and Control, Proceedings of the IMACS European Meeting, 521-526.

Raman, H., e Ramkumar., G. (1988) Simulation model for analysis of waiting time of ships and berth occupancy in ports. Journal of the Institution of Engineers, Part MA: Marine Engineering Division, v. 68, n.

Santos Port Authority. (2020) Terminais Portuários. Obtido 30 de maio de 2020, de http://www.portodesantos.com.br/institucional/terminais-portuarios/

Sheikh, A. A. R. E., Paul, R. J., Harding, A. S., e Balmer, D. W. (1987) A microcomputer-based simulation study of a port. Journal of the Operational Research Society, 38(8), 673-681. doi:10.1057/jors.1987.116

Silva, L. C. da. (2010) Estruturas para armazenagem a granel. Boletim Técnico, Universidade Federal do Espírito Santo., (2), 1-10. Obtido de http://www.agais.com/manuscript/ag0210_armazenagem_granel.pdf

Soros, P., e Zador, A. (1977) Bulk port planning by computer simulation. Dock and Harbour Authority, v. 58, n.

Taha, H. A. (2008) Pesquisa Operacion. (8 ${ }^{\mathrm{a}}$ Ed.). Pearson Educación.

Thiers, G. F., e Janssens, G. K. (1998) A Port Simulation Model as a Permanent Decision Instrument. Simulation, 71(2), 117-125. doi:10.1177/003754979807100206

Tovar, A., e Ferreira, G. (2006) A infra-estrutura portuária brasileira: o modelo atual e perspectivas para seu desenvolvimento sustentado. Revista do BNDES, 13(25), 209-230. Obtido de http://www.bndespar.gov.br/SiteBNDES/export/sites/default/bndes_pt/Galerias/Arquivos/c onhecimento/revista/rev2508.pdf

Tsinker, G. P. (1997) Handbook of Port and Harbor Engineering. Handbook of Port and Harbor 
Engineering. doi:10.1007/978-1-4757-0863-9

Van Vianen, T. A., Ottjes, J. A., Negenborn, R. R., Lodewijks, G., e Mooijman, D. L. (2012) Simulation-based operational control of a dry bulk terminal. Proceedings of 2012 9th IEEE International Conference on Networking, Sensing and Control, ICNSC 2012, 73-78. doi:10.1109/ICNSC.2012.6204894

Wadhwa, L. C.; James, M. K.; Vincent, M. W. (1980) Modelling and simulation of port operations. Forum papers, Australian Transport Research Forum.

Wright, C. L., Meyer, R. L., e Walker, F. E. (1983) Modelling improvements in transport infrastructure in developing areas. A Brazilian example. Journal of Development Economics, 12(1-2), 153-168. doi:10.1016/0304-3878(83)90036-6

Yakimov, I., Kirpichnikov, A., Mokshin, V., Yakhina, Z., e Gainullin, R. (2017) The comparison of structured modeling and simulation modeling of queueing systems. Communications in Computer and Information Science, 800, 256-267. doi:10.1007/978-3-319-68069-9_21

Zampirolli, J. M., e Botter, R. C. (2017) Alternativas Para Aumento De Capacidade De Um Terminal Portuário De Minério De Ferro. REVISTA ELETRÔNICA DE ESTRATÉGIA \& NEGÓCIOS, 10(55), 80-102. Obtido de http://search.ebscohost.com/login.aspx?direct=true\&amp;db=aph\&amp;AN=123884357\&a mp;lang=pt-br\&amp;site=ehost-live 